\title{
Glial Cell Line-Derived Neurotrophic Factor Requires Transforming Growth Factor- $\beta$ for Exerting Its Full Neurotrophic Potential on Peripheral and CNS Neurons
}

\author{
Kerstin Krieglstein, ${ }^{1}$ Prisca Henheik, ${ }^{1}$ Lilla Farkas, ${ }^{1}$ Jozsef Jaszai, ${ }^{1}$ Dagmar Galter, ${ }^{1}$ Knut Krohn ${ }^{2}$, and \\ Klaus Unsicker ${ }^{1}$ \\ ${ }^{1}$ Department of Neuroanatomy, University of Heidelberg, D-69120 Heidelberg, Germany and ${ }^{2}$ Center for Internal \\ Medicine, University of Leipzig, D-04103 Leipzig, Germany
}

Numerous studies have suggested that glial cell line-derived neurotrophic factor (GDNF) is a potent neurotrophic molecule. We show now on a variety of cultured neurons including peripheral autonomic, sensory, and CNS dopaminergic neurons that GDNF is not trophically active unless supplemented with TGF- $\beta$. Immunoneutralization of endogenous TGF- $\beta$ provided by serum or TGF- $\beta$-secreting cells, as e.g., neurons, in culture abolishes the neurotrophic effect of GDNF. The dose-response relationship required for the synergistic effect of GDNF and TGF- $\beta$ identifies $60 \mathrm{pg} / \mathrm{ml}$ of either factor combined with 2 $\mathrm{ng} / \mathrm{ml}$ of the other factor as the $\mathrm{EC}_{50}$. GDNF/TGF- $\beta$ signaling employs activation of phosphatidylinositol-3 (PI-3) kinase as an intermediate step as shown by the effect of the specific PI-3 kinase inhibitor wortmannin. The synergistic action of GDNF and TGF- $\beta$ involves protection of glycosylphosphatidylinositol (GPI)-linked receptors as shown by the restoration of their trophic effects after phosphatidylinositol-specific phospho- lipase C-mediated hydrolysis of GPI-anchored GDNF family receptor $\alpha$. The biological significance of the trophic synergism of GDNF and TGF- $\beta$ is underscored by colocalization of the receptors for TGF- $\beta$ and GDNF on all investigated GDNFresponsive neuron populations in vivo. Moreover, the in vivo relevance of the TGF- $\beta$ /GDNF synergism is highlighted by the co-storage of TGF- $\beta$ and GDNF in secretory vesicles of a model neuron, the chromaffin cell, and their activity-dependent release. Our results broaden the definition of a neurotrophic factor by incorporating the possibility that two factors that lack a neurotrophic activity when acting separately become neurotrophic when acting in concert. Moreover, our data may have a substantial impact on the treatment of neurodegenerative diseases.

Key words: motoneurons; dopaminergic neurons; neurotrophic factors; exocytosis; chromaffin cells; neurodegenerative disease; signal transduction
The discovery of glial cell line-derived neurotrophic factor (GDNF) as a neurotrophic factor for midbrain dopaminergic neurons was a hallmark in the search for novel molecules that may have relevance in the treatment of neurodegenerative diseases, as e.g., Parkinson's disease (PD; Lin et al., 1993). The significance of GDNF is underscored by its efficacy in several animal models of PD, including nonhuman primates (Hoffer et al., 1994; Beck et al., 1995; Tomac et al., 1995a; Sauer et al., 1995; Gash et al., 1996), ubiquitous expression in neurons of the CNS (Pochon et al., 1997), and its widening spectrum of responsive neuron populations (Henderson et al., 1994; Arenas et al., 1995; Buj-Bello et al., 1995; Trupp et al., 1995; Farkas et al., 1997). GDNF signals via the tyrosine kinase receptor c-Ret (Durbec et al., 1996; Trupp et al., 1996) in cooperativity with a glycosylphosphatidylinositol (GPI)-linked $\alpha$ receptor, the GDNF family receptor $\alpha(\mathrm{GFR} \alpha)$ (Jing et al., 1996; Treanor et al., 1996). GDNF is a member of the TGF- $\beta$ superfamily (Kingsley, 1994), its

Received March 10, 1998; revised Sept. 16, 1998; accepted Sept. 17, 1998.

This work was supported by grants from Deutsche Forschungsgemeinschaft (SFB 317/D4, Un34/19-1-A2, and Un34/20-1) and BioMedII (BMH4-97-215). We thank Drs. D. Rifkin (New York University), W. Huttner (University of Heidelberg), V. Rosen (Genetics Institute, Cambridge, MA), and M. B. Sporn (Dartmouth Medical College, Hanover, NH). We also thank Ms. Jutta Fey, Ulla Hinz, Daniela Oguntke, and Ingrid Stenull for excellent technical assistance.

Correspondence should be addressed to Dr. Kerstin Krieglstein, Department of Neuroanatomy, University of Heidelberg, Im Neuenheimer Feld 307, D-69120 Heidelberg, Germany.

Copyright (C) 1998 Society for Neuroscience $\quad 0270-6474 / 98 / 189822-13 \$ 05.00 / 0$ closest relative being neurturin (Kotzbauer et al., 1996). Targeted mutations of the GDNF (Moore et al., 1996; Pichel et al., 1996; Sanchez et al., 1996) or c-Ret genes (Schuchardt et al., 1994) have indicated that GDNF is essentially required for the development of the kidney, major portions of the enteric nervous system, and the sympathetic superior cervical ganglion.

TGF- $\beta$ s are widely distributed and contextually acting cytokines with prominent roles in development and cell cycle control (Roberts and Sporn, 1990; Nathan and Sporn, 1991; Alexandrow and Moses, 1995; Krieglstein et al., 1995a). TGF- $\beta$ s have been implicated in the regulation of neuronal survival of, e.g., motoneurons (Martinou et al., 1990), sensory neurons (Chalazonitis et al., 1992), and midbrain dopaminergic neurons (Krieglstein and Unsicker, 1994; Poulsen et al., 1994). It should be noted, however, that TGF- $\beta$ shows no or marginal effects on highly enriched, serum-free neuron cultures, as e.g., sensory neurons (Krieglstein and Unsicker, 1996b), suggesting that TGF- $\beta$ may require cooperating factors for eliciting its trophic effects.

Several lines of evidence suggest that GDNF similarly may require cofactors for acting as a neurotrophic factor. First, GDNF does not support the survival of most peripheral neurons in low-density dissociated cultures and defined media (Henderson et al., 1994; Krieglstein and Unsicker, 1996a). Second, follow-up experiments in which GDNF was shown to promote the survival of enriched peripheral autonomic and sensory neurons (Buj-Bello et al., 1995; Trupp et al., 1995) were all performed using serum throughout the whole culture period. Third, the dopaminotrophic 
effect of GDNF was established in an extremely complex culture system (Lin et al., 1993) in which its most prominent effect did not become apparent until day 7 in culture.

The present study identifies TGF- $\beta$ as the cotrophic factor required to permit neurotrophic effects of GDNF.

\section{MATERIALS AND METHODS}

Cell cultures. Fertilized white Leghorn chicken eggs were incubated in a humidified egg chamber at $37.8^{\circ} \mathrm{C}$. Rat embryos were obtained from Hanover-Wistar rats; the day of vaginal plug identification was considered embryonic day 0 (E0). Embryonic chick (E8, E10, and E12) ciliary, dorsal root, and sympathetic ganglia and embryonic (E14) rat dorsal root ganglia were dissected, freed from nerve roots and connective tissue, and collected in $\mathrm{Ca}^{2+} / \mathrm{Mg}^{2+}$-free HBSS (CMF; Sigma, St. Louis, MO). Ganglia were trypsinized, washed in $\mathrm{CMF}$, and triturated as described (Lachmund et al., 1994). Single cell suspensions were seeded in poly-Lornithine (PORN), laminin-coated microtiter plates (Costar, Cambridge, MA; A/2) at a density of 1200 cells per well in DMEM supplemented with $\mathrm{N} 1$ additives (transferrin, $6.25 \times 10^{-8} \mathrm{M}$; putrescine, $1 \times 10^{-4} \mathrm{M}$; progesterone, $2 \times 10^{-8} \mathrm{M}$; and selenium, $3 \times 10^{-8} \mathrm{M}$; Sigma; Bottenstein et al., 1980), 0.25\% BSA (Sigma), $100 \mathrm{U} / \mathrm{ml}$ penicillin, $0.50 \mu \mathrm{g} / \mathrm{ml}$ streptomycin, $100 \mu \mathrm{g} / \mathrm{ml}$ neomycin (PSN) (Life Technologies), and incubated at $37^{\circ} \mathrm{C}$ in a $5 \% \mathrm{CO}_{2}$ and $95 \%$ air atmosphere (Lachmund et al., 1994).

Mesencephalic cell cultures from embryonic rat midbrain floor (E14) were essentially established as described by Krieglstein et al. (1995b). They were seeded at a density of 50,000 per $\mathrm{cm}^{2}$, cultured under serumfree conditions, and processed for immunocytochemistry on day 5 in vitro. Dopaminergic neurons were visualized using a monoclonal antibody to rat tyrosine hydroxylase (1:200, Boehringer Mannheim, Mannheim, Germany) as described previously (Krieglstein et al., 1995b).

Embryonic rat motoneurons (Hanover-Wistar rats, E14) were prepared as described by Camu and Henderson (1992) using a two-step purification method: a density centrifugation using a metrizamide gradient followed by a panning procedure using the monoclonal antibody MC-192 that recognizes the low-affinity NGF receptor. The purified motoneurons were seeded in 24-well plates (Nunc, Darmstadt, Germany; 1000 per well) coated with PORN/laminin. After $15 \mathrm{hr}$ all phase-bright cells without vacuolar inclusions were counted to establish the $100 \%$ value, and the neurotrophic factors were added. On day 4 in culture the percentage of surviving motoneurons was established by a final counting.

Neurons were grown with or without different recombinant neurotrophic factors [NGF, Boehringer Mannheim; CNTF, GDNF, FGF-2, and TGF- $\beta 2$, IC Chemikalien; TGF- $\beta 1$ and TGF- $\beta 3$, a gift from Dr. M.B. Sporn; bone morphogenetic proteins (BMPs) 2, 4, 6, 7, and 12, provided by Dr. V. Rosen, Genetics Institute; protein lysate from bovine chromaffin granules, Krieglstein and Unsicker, 1997], serum (horse serum, Life Technologies; fetal calf serum, PAA laboratories, EuroBio, PAN Systems), or neutralizing antibodies to TGF- $\beta 1$, TGF- $\beta 2$, and TGF- $\beta 3$ (10 $\mu \mathrm{g} / \mathrm{ml}$; Genzyme, Boston, MA; catalog \#1835-01) or to GDNF (20 $\mu \mathrm{g} / \mathrm{ml}$; Santa Cruz Biotechnology, Santa Cruz, CA). Chick ciliary ganglia (CG) neurons were grown in the presence of wortmannin (Calbiochem, La Jolla, CA) or were incubated for $1 \mathrm{hr}$ at $37^{\circ} \mathrm{C}$ with $100 \mathrm{mU}$ phosphatidylinositol-specific phospholipase C (PIPLC) (Boehringer Mannheim) or $100 \mathrm{mU}$ PIPLC plus $2 \mathrm{ng} / \mathrm{ml}$ TGF- $\beta 1$, or they were incubated without enzyme before the addition of growth factors. At appropriate times [CG, $24 \mathrm{hr}$; DRG, $48 \mathrm{hr}$, lumbar sympathetic ganglia (SG), $72 \mathrm{hr}$ ] cultures were fixed by addition of $2.5 \%$ glutaraldehyde in PBS. Numbers of surviving neurons were determined by direct counting of $30 \%$ of the surface area using phase contrast microscopy.

The isolation of bovine adrenal medullary chromaffin cells was performed by collagenase digestion and Percoll gradient centrifugation essentially as described by Unsicker et al. (1980). Chromaffin cells at $95 \%$ purity were seeded into $25 \mathrm{~cm}^{2}$ plastic culture flasks (Falcon) at a density of 200,000 cells $/ \mathrm{cm}^{2}$ and grown in $5 \mathrm{ml}$ DMEM/N1. After $30 \mathrm{hr}$ the cultures were washed three times with medium and incubated for $15 \mathrm{~min}$ at $37^{\circ} \mathrm{C}$ in $2 \mathrm{ml}$ prewarmed DMEM/N1 with or without of the following secretagogues: carbachol (100 $\mu \mathrm{M}$; Sigma), carbachol $(100 \mu \mathrm{M})$ plus verapamil (10 $\mu \mathrm{M}$; Sigma), or the calcium ionophore A23187 (2 $\mu \mathrm{M}$; Sigma).

B49, COS cells, and NIH 3T3 fibroblasts were grown in 10\% FCSDMEM with PSN, and baby hamster kidney cells in DMEM-F12 with $5 \%$ FCS and PSN in plastic culture flasks (Falcon). Conditioned medium of confluent cultures was collected over a period of $48 \mathrm{hr}$. Determination of TGF $\beta$ activity was performed by using mink lung epithelial cells (MLEC) stably transfected with a luciferase reporter gene under the control of a truncated PAI-1 promotor (Abe et al., 1994; kindly provided by Dr. Rifkin, New York University) as described earlier (Krieglstein and Unsicker, 1995). Transfected MLEC cultures were plated in a 96-well microtiter plate (Costar) at a density of $1.6 \times 10^{4}$ cells per well in DMEM (high glucose) with $10 \% \mathrm{FCS}$ and geneticin $(250 \mu \mathrm{g} / \mathrm{ml})$ and allowed to attach for $3 \mathrm{hr}$ at $37^{\circ} \mathrm{C}$ in a $5 \% \mathrm{CO}_{2}$ incubator. The medium was then replaced with $100 \mu \mathrm{l}$ of test sample and incubated overnight at $37^{\circ} \mathrm{C}$ in a $5 \% \mathrm{CO}_{2}$ incubator. Cells were washed twice with PBS and lysed by using $100 \mu \mathrm{l}$ of lysis buffer (Promega, Madison, WI) for 2-3 hr at RT. To determine TGF- $\beta$ activity, $80 \mu$ l of the lysates were transferred to a test tube and analyzed using a Luminometer (EG\&G Berthold, Bad Wildbach, Germany) by $100 \mu \mathrm{l}$ injections of luciferase reagent (Berthold Detection Systems, Pfortzheim, Germany). Luciferase activity was reported as relative light units (RLU), and all assays were performed in triplicate.

$R T-P C R$. RT-PCR was used to determine the expression pattern of TGF- $\beta 2$ and TGF- $\beta 3$ along with T $\beta$ R-II, GFR $\alpha-1$, and c-ret (receptor components involved in TGF- $\beta$ or GDNF signaling) in postnatal day 0 (P0) ventral mesencephalon, dorsal root ganglia, and E14 purified motoneurons. Expression of TGF- $\beta 1$, TGF- $\beta 2$, TGF- $\beta 3$, and GDNF was also determined in dissociated purified bovine adrenal chromaffin cells. Total RNA was isolated by Trizol (Life Technologies) according to the manufacturer's instruction and were treated with RQ1 DNase (Promega) to exclude amplification of contaminating genomic DNA in subsequent manipulations. Total RNA was subjected to reverse transcription. Total RNA $(1 \mu \mathrm{g} /$ reaction) was added to a "master mix" $(24 \mu \mathrm{l})$ containing final concentrations of $0.5 \times$ first strand buffer (Life Technologies), $0.66 \mathrm{U} / \mu \mathrm{l}$ RNase inhibitor (MBI Fermentas), $10 \mathrm{~mm}$ dithiothreitol (DTT), $1.5 \mu \mathrm{M}$ oligo-dT primer (Life Technologies), and $0.3 \mathrm{~mm}$ deoxyribonucleoside triphosphates (dNTPs) (Pharmacia, Freiburg, Germany). Sample mixtures were then heated to $65^{\circ} \mathrm{C}$ for $10 \mathrm{~min}$. After cooling to $42^{\circ} \mathrm{C}, 200 \mathrm{U}(5 \mu \mathrm{l}) \mathrm{M}-\mathrm{MLV}$ reverse transcriptase (Life Technologies) and $5 \times$ first strand buffer to a final concentration of $1 \times$ were added. Reactions were incubated at $37^{\circ} \mathrm{C}$ for $60 \mathrm{~min}$ and were then stopped by incubation at $75^{\circ} \mathrm{C}$ for $10 \mathrm{~min}$. After reverse transcription each cDNA sample was subjected to PCR amplification using specific primers as follows: TGF- $\beta 1$ forward 5'AAGAACTGCTGTGTTCGTCAGC-3' and reverse $5^{\prime}$-GATCATGTTGGACAACTGCTCC-3'; TGF- $\beta 2$ forward(bovine) $5^{\prime}$-TGGATGCCGCCTATTGCTTTAGG-3', forward (rat) 5'-CTACAGACTGGAGTCCCAGC-3', and reverse (bovine, rat) 5'-CATGTTGGAAAGTTGTTCGATC-3'; TGF- $\beta 3$ forward (bovine, rat) $5^{\prime}$-GGAAATCAAATTCAA AGGAGTGG-3' and reverse (bovine, rat) 5'-AGTTGGCATAGTAACCCTTAGG-3'; GDNF forward 5'-GGTCTACGGAGACCGGATCCGAGGTGC-3' and reverse $5^{\prime}$-TCTCTGGAGCCAGGGTCAGATACATC-3'; T $\beta$ R-II forward 5'-GCTGCATATCGTCCTGTG-3' and reverse 5'-CGTGGTAGGTGAGCTTGG-3'; GFR $\alpha$-1 (Baloh et al., 1997) forward 5'-GCACAGCTACGGGATGCTCTTCTG-3' and reverse 5'-GTAGTTGGGAGTCATGACTGTGCCAATC-3'; c-ret (Baloh et al., 1997) forward 5'-TGGCACACCTCTGCTCTATG-3' and reverse $5^{\prime}$-TGTTCCCAGGAACTGTGGTC-3'; and S6 forward 5'-CTCCAAAGAAGATGATGTCC-3' and reverse 5'-TTTAGAAGTAGAAGCTCTCAG-3'. PCR reactions were performed in $0.2 \mathrm{ml}$ thin-walled reaction tubes using the "hot-start" method in a Perkin-Elmer GeneAmp PCR system 9600. Reagents were assembled in a final volume of $50 \mu \mathrm{l}$, and final concentrations of reagents were as follows: $5 \mu \mathrm{l}$ first strand cDNA, $1 \mu \mathrm{M}$ forward primer, $1 \mu \mathrm{M}$ reverse primer, $1 \times$ PCR buffer (Life Technologies), $1 \mathrm{~mm}$ $\mathrm{MgCl}_{2}, 100 \mathrm{~mm}$ dNTPs (Pharmacia) and RNase-free water to $50 \mu \mathrm{l}$. Samples were initially denatured at $94^{\circ} \mathrm{C}$ for $4 \mathrm{~min}$ and $1.25 \mathrm{U}$ recombinant Taq DNA polymerase (Life Technologies) was then added. Thermocycling parameters were then $30 \mathrm{sec}$ denaturation at $95^{\circ} \mathrm{C}, 30 \mathrm{sec}$ annealing at $60^{\circ} \mathrm{C}$, and $30 \mathrm{sec}$ extension at $72^{\circ} \mathrm{C}$ repeated for 32 cycles with a final extension step at $72^{\circ} \mathrm{C}$ for $5 \mathrm{~min}$. Aliquots $(5 \mu \mathrm{l})$ of the PCR reaction were run on $0.2 \%$ agarose gels, and the size of the reaction products was determined after ethidium bromide staining. Identity of TGF- $\beta$ reaction products (TGF- $\beta 1$, TGF-2, and TGF-3) was confirmed by Southern blotting and hybridization. Five microliters of each TGF $\beta$ and S6 amplification products were run on $2 \%$ agarose gels and blotted to Hybond- $\mathrm{N}^{+}$nylon membranes (Amersham, Braunschweig, Germany). Membranes were probed using internal oligonucleotide sequences (TGF- $\beta 1$ 5'-TTGGGCTTGCGACCCACGTAGT-3'; TGF- $\beta 2$ 5'-TGGATGCCGCCTATTGCTTTAGG-3'; TGF- $\beta 3$ 5'-AGATGACCATGGCCGTGGAGACC-3'; and S6 $5^{\prime}$ GGAGGCTGCAGAATATGCTAAACT-3') labeled with TdT (terminal deoxynucleotidyl transferase; AGS, Heidelberg, Germany) using ${ }^{32} \mathrm{P}$ - 
gamma-ATP (DuPont NEN, Boston, MA). Signal intensities were analyzed by ImageQuant/PhosphorImager (Molecular Dynamics).

Immunohistochemistry, immunoprecipitation, and Western blotting. Immunohistochemistry was essentially performed as described previously (Krieglstein et al., 1996). White Leghorn chick embryos (E8) were fixed by immersion in ice-cold Bouin solution for $4 \mathrm{hr}$ (Krieglstein et al., 1998). Pregnant Wistar rats were killed by $\mathrm{CO}_{2}$ aspiration, and embryos (E21) were removed and fixed by transcardial perfusion with $4 \%$ paraformaldehyde buffered in PBS. The spinal cord of newborn (P0) Wistar rats was removed after transcardial perfusion with $10 \%$ neutral buffered formol and post-fixed in Bouin solution. Tissue pieces were dehydrated in increasing concentrations of ethanol and embedded in paraffin wax. Sections $(10 \mu \mathrm{m})$ from E21 rat adrenal glands were deparaffinized and incubated for $30 \mathrm{~min}$ in $10 \%$ horse serum (HS), $1 \%$ BSA, and $0.1 \%$ Triton X-100. Sections were then exposed to either anti-chromogranin A antibody (rabbit polyclonal 1:200, Dakopatts, Copenhagen, Denmark; or mouse monoclonal 1:100, kindly provided by Dr. W. Huttner, University of Heidelberg) at $4^{\circ} \mathrm{C}$ overnight, followed by incubation with anti-GDNF antibody (rabbit polyclonal 1:200, Santa Cruz Biotechnology; or mouse monoclonal 1:100, R \& D Systems, Minneapolis, MN). As a specificity control, consecutive rather than identical sections were incubated with just one primary antibody at a time and processed similarly. Specificity of the stainings was verified by omitting the first antibody, by preabsorbing with an excess of antigen (rhGDNF, bovine chromaffin granule lysates containing chromogranin A), and by Western blotting of bovine chromaffin cell and granule lysates (see this study and Huttner et al., 1991; Bieger et al., 1995; Krieglstein et al., 1996). Cultured bovine chromaffin cells were processed similarly after a 10 min fixation using $4 \%$ paraformaldehyde buffered with PBS. Paraffin sections $(5-10 \mu \mathrm{m})$ from rat spinal cord $(\mathrm{P} 0)$ or chicken DRG (E8) were rehydrated, and antigen unmasking was performed by microwave treatment in $10 \mathrm{~mm}$ citrate buffer. After blocking with serum, sections were immunostained for TGF- $\beta 2$, TGF- $\beta 3$, or T $\beta$ R-II (TGF- $\beta 2$, sc-90; TGF- $\beta 3$, sc- 82 ; and T $\beta$ RII, sc-400, Santa Cruz Biotechnology) using the isoform-specific antibodies at dilutions of 1:200-1:500. The immunostaining was visualized using the streptavidin-Cy3 method as previously described (Krieglstein et al., 1996). Experimental controls were performed by replacing the primary antibody with normal rabbit serum, preincubation with the corresponding antigen, and by immunoprecipitation (data not shown, Unsicker et al., 1996; Krieglstein et al., 1998).

For immunoprecipitation of GDNF or TGF- $\beta 1$, samples were incubated with $10 \mu \mathrm{l} / \mathrm{ml}$ of the appropriate agarose-conjugated antibody (polyclonal rabbit anti-GDNF or anti-TGF- $\beta 1$, Santa Cruz Biotechnology) at $4^{\circ} \mathrm{C}$ overnight under mild agitation. Samples were washed with PBS and then resuspended in $50 \mu \mathrm{l}$ of electrophoresis sample buffer and boiled for $2 \mathrm{~min}$. Samples were separated by electrophoresis on a $12.5 \%$ SDS-polyacrylamide gel and transferred to nitrocellulose membrane (Hybond; Amersham) as described earlier (Bieger et al., 1995). For dot blot analysis $2 \mu \mathrm{l}(40 \mathrm{ng})$ of each growth factor sample was loaded onto nitrocellulose membrane. The membranes were blocked with $3 \%$ low fat milk powder and $0.1 \%$ BSA in Tris-buffered saline (TBS), pH 7.3, incubated with primary antibody (1:200 in 0.1\% BSA-TBS) overnight at $4^{\circ} \mathrm{C}$ followed by peroxidase conjugated anti-rabbit antibody (1:2000 in $0.1 \%$ BSA-TBS). Finally, the membrane was developed using the Amersham enhanced chemiluminescence (ECL) detection system.

\section{RESULTS}

\section{The neurotrophic action of GDNF on several populations of peripheral and CNS neurons essentially requires TGF- $\beta$}

GDNF has been proposed as a potent neurotrophic factor for a variety of cultured CNS and peripheral neurons. All of these cultures share significant cellular complexity and/or the use of serum resulting in uncontrolled trophic conditions. A well known constituent of almost every cell type as well as serum is TGF- $\beta$ (Roberts and Sporn, 1990). Quantitative determinations of TGF- $\beta$ (biological activity) in cultures of B49 (from which GDNF was originally isolated), BHK, COS cells, and 3 T3 fibroblasts (frequently used for transfection experiments) revealed that these cells secrete within $48 \mathrm{hr} 0.2$ to $0.4 \mathrm{ng} / \mathrm{ml} \mathrm{TGF}-\beta$ into their culture medium (data not shown; cf. Abe et al., 1994; Krieglstein and Unsicker, 1995). Different batches of fetal calf and horse sera contain varying, but significant amounts of TGF- $\beta(0.1-0.2 \mathrm{ng} / \mathrm{ml}$ in culture media with $10 \%$ serum; data not shown).

Using chick ciliary ganglionic neurons as an example, Figure $1 A$ demonstrates that GDNF supplemented with $10 \%$ horse serum maintains neurons over a $24 \mathrm{hr}$ period as effectively as a saturating concentration of CNTF $(5 \mathrm{ng} / \mathrm{ml})$. However, administering culture medium that had been preincubated with neutralizing antibodies to TGF- $\beta$ (10 $\mu \mathrm{g} / \mathrm{ml}$, known to neutralize $>95 \%$ of $1 \mathrm{ng} / \mathrm{ml}$ of TGF- $\beta$ isoforms TGF- $\beta 1$, TGF- $\beta 2$, and TGF- $\beta 3$; for specificity of the antibody, see Fig. $1 B$ ) significantly reduced the effect of GDNF, suggesting that GDNF requires TGF- $\beta$ for displaying its trophic effect. Consistent with this notion, if a serum-containing culture medium was replaced with a fully defined culture medium, both GDNF and TGF- $\beta$ alone (each at the saturating amount of $2 \mathrm{ng} / \mathrm{ml}$ ) showed only marginal survivalpromoting effects. However, when combined, the two factors promoted neurons as effectively as CNTF. To determine doseresponse relationships required for the synergistic effect of GDNF and TGF- $\beta$, each single factor at a concentration of 2 $\mathrm{ng} / \mathrm{ml}$ was titrated in combination with serial dilutions of the other one. As shown in Figure $1 C, 60 \mathrm{pg} / \mathrm{ml}$ of either factor combined with $2 \mathrm{ng} / \mathrm{ml}$ of the other factor represented the $\mathrm{EC}_{50}$. The combination of $0.25 \mathrm{ng} / \mathrm{ml}$ and $2 \mathrm{ng} / \mathrm{ml}$ already elicited saturating effects. All isoforms of TGF- $\beta$ (TGF- $\beta 1$, TGF- $\beta 2$, and TGF- $\beta 3$ ) were consistently equipotent under the conditions used (data not shown). TGF- $\beta$ could not be replaced by BMP2, 4, 7, or 12 (data not shown). We conclude that the combination of purified recombinant TGF- $\beta$ and GDNF promotes ciliary ganglionic neuron survival to the same extent as CNTF, whereas each single factor is virtually ineffective. The combinatorial effect is specific in that TGF- $\beta$ cannot be replaced by other members of the TGF- $\beta$ superfamily.

To investigate whether the synergistic effect of GDNF and TGF- $\beta$ also applied to other populations of peripheral neurons, identical experiments were performed using chick sensory (DRG) and paravertebral sympathetic neurons isolated from E8 embryos. As shown in Figure 1, $D$ and $E$, GDNF and TGF- $\beta$, when coadministered to serum-free cultures, maintained sensory and sympathetic neurons, respectively, as supported by a saturating concentration of NGF (5 ng/ml). Again, $10 \%$ horse serum substituted for TGF- $\beta$.

To exclude that the above effects are restricted to a brief developmental time window, the same set of experiments was performed on ciliary, sensory DRG and sympathetic neurons from E10 and E12 chick embryos. Figure $2 A, B$ shows that coadministration of GDNF and TGF- $\beta$ mimicked the survivalpromoting effect of CNTF or NGF, respectively, at all ages and on all neuron populations studied.

To establish that neurons from chick as well as mammals responded in a similar manner to GDNF and TGF- $\beta$, lumbar DRG neurons from E14 rat embryos were subject to the same treatments as above. Figure $3 A$ shows that, in contrast to NGF, the GDNF-mediated survival-promoting effect in the presence of $10 \%$ horse serum was abolished by a saturating amount (10 $\mu \mathrm{g} / \mathrm{ml}$ ) of neutralizing antibodies to TGF- $\beta$.

As GDNF was first characterized by its pronounced trophic effects on midbrain dopaminergic neurons, we asked whether this effect was dependent on or independent from TGF- $\beta$. As shown in Figure $3 B$, GDNF and TGF- $\beta$ each promoted the survival of dopaminergic neurons under serum-free conditions approximately twofold as compared with untreated control cultures. Combinations of the factors further enhanced survival (threefold 
A
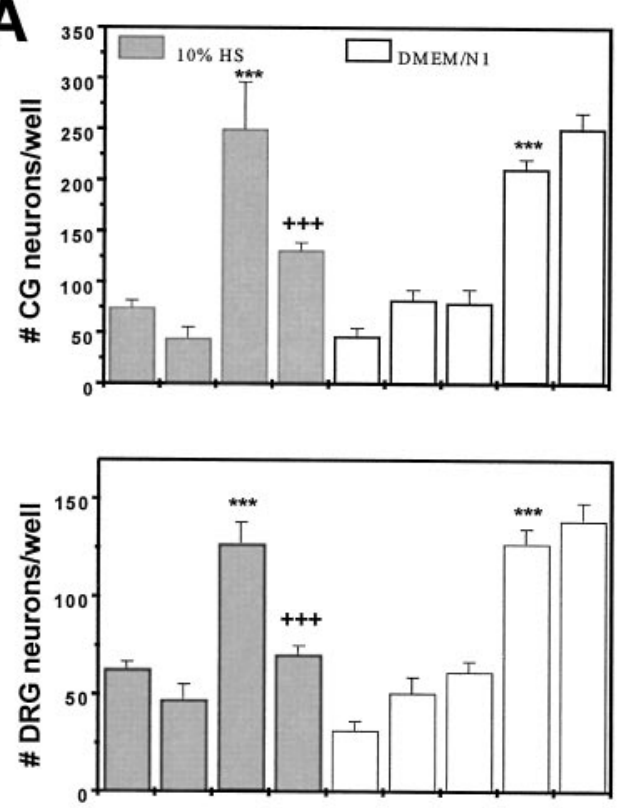

C

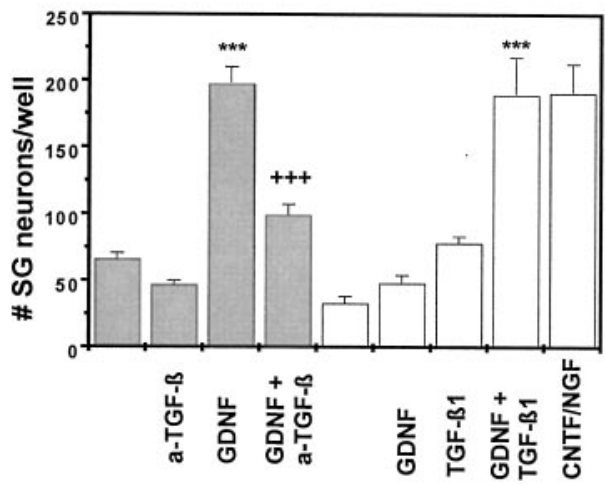

B
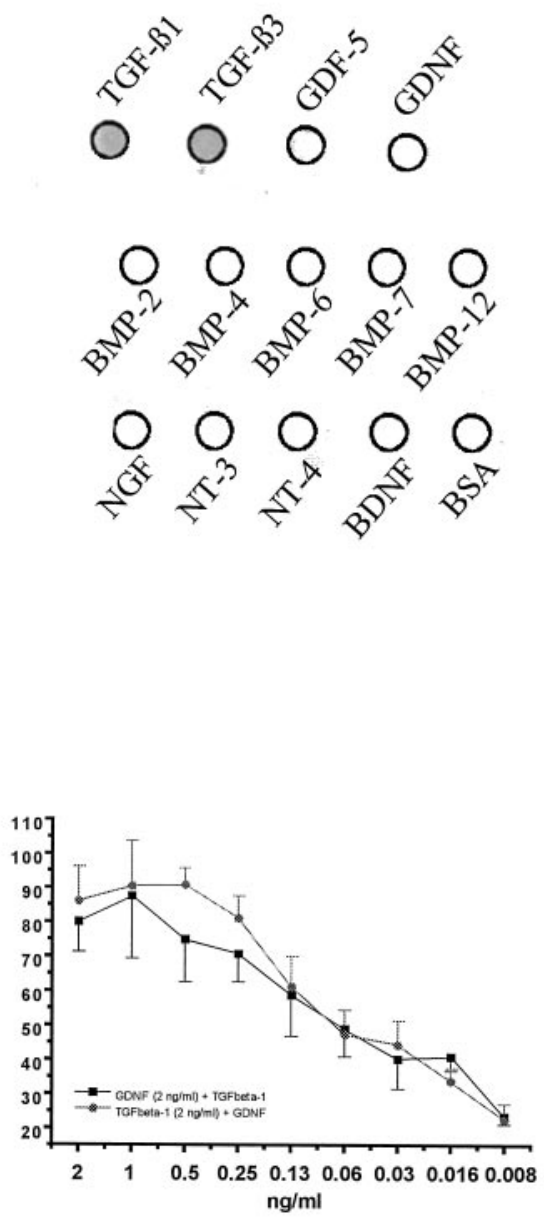

Figure 1. Survival of peripheral autonomic and sensory neurons by the synergistic action of GDNF and TGF- $\beta$. $A$, Neurons from CG, DRG, and SG ganglia were isolated at E8 and grown under the indicated conditions. Neurons were maintained in serumcontaining medium (10\% HS) (gray bars) or in serum-free medium (white bars). In the presence of serum, addition of a saturating concentration of GDNF promoted survival of each of the three neuron populations at levels identical to those achieved by addition of the respective neurotrophic factor (CNTF for CG, NGF for DRG and SG neurons; $10 \mathrm{ng} / \mathrm{ml}$ each) to serum-free culture media. Addition of a neutralizing antibody to TGF- $\beta 1$, TGF- $\beta 2$, and TGF- $\beta 3$ (a-TGF- $\beta, 10 \mu \mathrm{g} / \mathrm{ml}$ ) reduced neuron survival to levels seen with the addition of serum alone, suggesting that GDNF required TGF- $\beta$ in the serum to achieve its survival-promoting effect. In serum-free conditions, GDNF and TGF- $\beta-1$ ( $2 \mathrm{ng} / \mathrm{ml})$, when added separately had virtually no survival-promoting effect. However, when combined at optimal concentrations, both factors permitted neuron survival at levels identical to those achieved with the established neurotrophic factors CNTF and NGF, respectively. Data are given as mean \pm SEM $(n=6), p$ values derived from Student's $t$ test are $* * * p<0.001$ for increased survival as compared with single factors and $+++p<0.001$ for decreased survival after antibody treatment. $B$, Dot blot showing that the anti-TGF- $\beta$ antibody recognizes TGF- $\beta 1$ and TGF- $\beta 3$, but not any other TGF- $\beta$ superfamily or neurotrophin family member tested. $C$, Doseresponse curve for the combined action of GDNF and TGF- $\beta$ on chick ciliary neurons. Squares represent neuron survival achieved in the presence of a constant amount of GDNF ( 2 ng/ml) plus the indicated amounts of TGF- $\beta 1$. Circles represent neuron survival achieved in the presence of a constant amount of TGF- $\beta 1$ ( 2 ng/ml) plus the indicated amounts of GDNF.

as compared with controls). Addition of neutralizing antibodies to TGF- $\beta(10 \mu \mathrm{g} / \mathrm{ml})$ abolished the trophic effect of GDNF.

Motoneurons have been the only neuron population studied so far that showed a convincing neurotrophic response to recombinant GDNF (cf. Henderson et al., 1994). Even so, as shown in Figure $3 C$, TGF- $\beta$ significantly enhanced the trophic effect of GDNF. In contrast to dopaminergic neurons, however, antibodies to TGF- $\beta(10 \mu \mathrm{g} / \mathrm{ml})$ failed to reduce survival in the absence of exogenous factors.

In summary, the above data indicate that TGF- $\beta$ is required to have GDNF exert its full neurotrophic potential on both peripheral and CNS neurons.

\section{TGF- $\beta$ synergizes with GDNF by protecting GPI-linked receptors}

To begin to characterize details of the specific signal transduction pathway used by GDNF to cooperate with TGF- $\beta$, we investigated whether activation of PI-3 kinase that has been shown as an early event in GDNF/c-ret-mediated signal transduction (van Weering and Bos, 1997) was involved. Figure $4 A$ shows that the specific PI-3 kinase inhibitor wortmannin at a concentration of
$0.25 \mu \mathrm{M}$ completely abolished the survival-promoting effect of GDNF in conjunction with TGF- $\beta$ on cultured ciliary ganglionic neurons. Wortmannin did not interfere with the survivalpromoting effect of CNTF, indicating that activation of PI-3 kinase is an essential event in mediating the survival-promoting effect of GDNF/TGF- $\beta$, but not that of CNTF. Furthermore, this result indicates that wortmannin did not unspecifically compromise survival.

We next asked whether TGF- $\beta$ might be involved in the stabilization and recruitment of the GPI-linked GFR $\alpha$. PIPLC at a concentration of $0.1 \mathrm{U} / \mathrm{ml}$ was used to hydrolyze the GPIanchored receptors on dissociated ciliary neurons before plating. This procedure effectively reduced the survival-promoting effect of CNTF (which utilizes the GPI-anchored GPAR $\alpha$; Heller et al., 1995) without affecting the survival-promoting effect of FGF-2 (Fig. 4B). Hydrolysis of GPI-linked receptors significantly reduced the survival-promoting effect of GDNF in its combination with TGF- $\beta$. However, when the PIPLC pretreatment was conducted in the presence of TGF- $\beta$ ( $2 \mathrm{ng} / \mathrm{ml}$ TGF- $\beta 1)$ the survivalpromoting effects of GDNF and CNTF were maintained (Fig. $4 B)$. These data suggest an essential involvement of a GPI-linked 
A
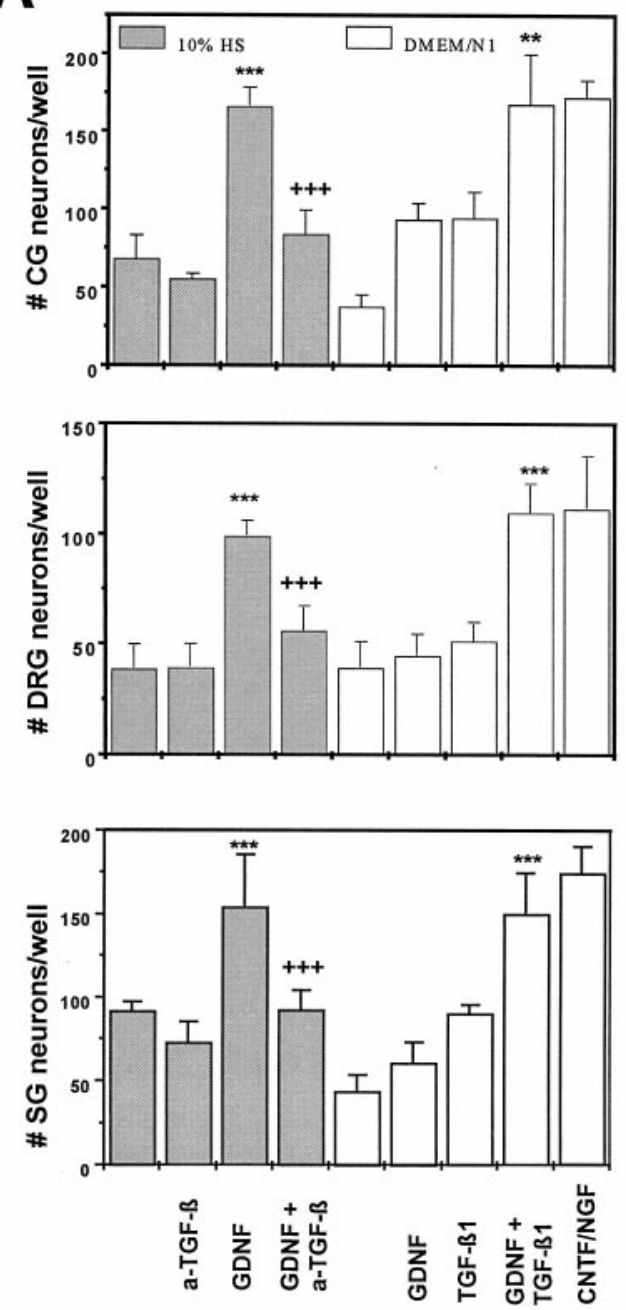

B
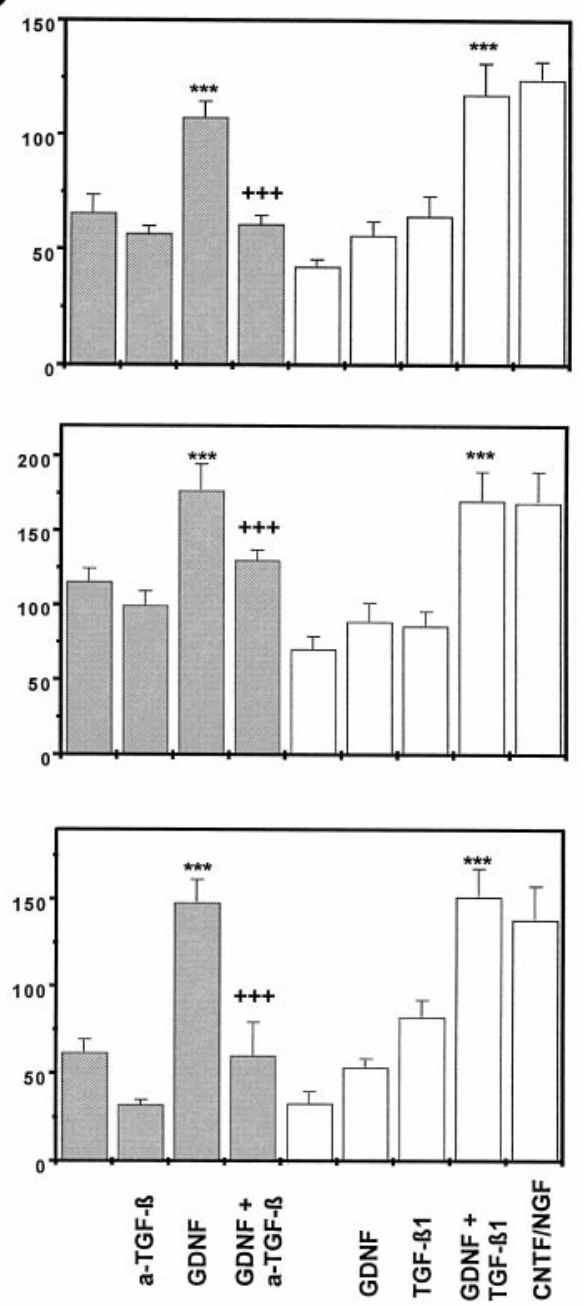

Figure 2. Assay as performed in Figure $1 A$ using neurons from the respective ganglia of chick E10 $(A)$ and E12 $(B)$ embryos. Data indicate that the GDNF/TGF- $\beta$ synergism also applies to neurons at more advanced stages of development. Data are given as mean \pm SEM $(n=6), p$ values derived from Student's $t$ test are ${ }^{* * *} p<0.001$ for increased survival as compared with single factors and $+++p<0.001$ for decreased survival after antibody treatment.

receptor component in the neurotrophic effect of GDNF and a possible role of TGF- $\beta$ in the stabilization and/or recruitment of the $\alpha$ receptor component.

\section{Expression of TGF- $\beta$ s and TGF- $\beta$ receptor (T $\beta$ R-II) in GDNF-responsive neuron populations in vivo}

To investigate whether neuron populations known to be responsive to GDNF coexpress TGF- $\beta$ receptor and its ligands in vivo, we studied expression of both mRNA and protein in select neurons of the CNS and peripheral nervous system. As shown in Figure 5 motoneurons purified from E14 rat spinal cord, DRG, and ventral mesencephalon from newborn rat expressed mRNA signals for TGF- $\beta 2$, TGF- $\beta 3$, and T $\beta$ R-II along with the GDNF receptors GFR $\alpha-1$ and c-ret. Figure 6 demonstrates the cellular localization of TGF- $\beta 2$, TGF- $\beta 3$, and T $\beta$ R-II immunoreactivities in DRG (E8 chick) and spinal motoneurons (neonatal rat). These data are supplemented by previously published results compiled in Table 1, showing that the investigated neuron populations are well equipped with receptors for GDNF and TGF- $\beta$ in vivo. Moreover, these neurons also express the ligand TGF- $\beta$, whereas GDNF is consistently found in neuronal target areas. Together, these data make a compelling case for an in vivo scenario of GDNF and TGF- $\beta$ cooperativity.

\section{Co-release of GDNF and TGF- $\beta$ from a model neuron, the chromaffin cell}

To further investigate the biological significance of the cotrophic action of GDNF and TGF- $\beta$ we studied their putative co-release. The best-established model system for studying secretion from a neuron is the chromaffin cell (Neher and Marty, 1982; Burgoyne et al., 1989; Huttner et al., 1991; Unsicker, 1993; Ferro-Novick and Jahn, 1994; Jahn and Südhoff, 1994). Chromaffin cells are known to store within their secretory granules ("chromaffin granules") and release after stimulation with a cholinergic agonist a neurotrophic activity, which has been shown to promote in vitro the survival of a number of neuron populations, including chick ciliary ganglionic neurons (Fig. 7; Unsicker and Lietzke, 1987; Lachmund et al., 1994; Unsicker and Krieglstein, 1996). Few protein growth factors have been identified in the past that can promote the survival of chick ciliary ganglionic neurons in vitro in the absence of serum. These are the ciliary neurotrophic factor (CNTF; Barbin et al., 1984), growth-promoting activity (GPA; 

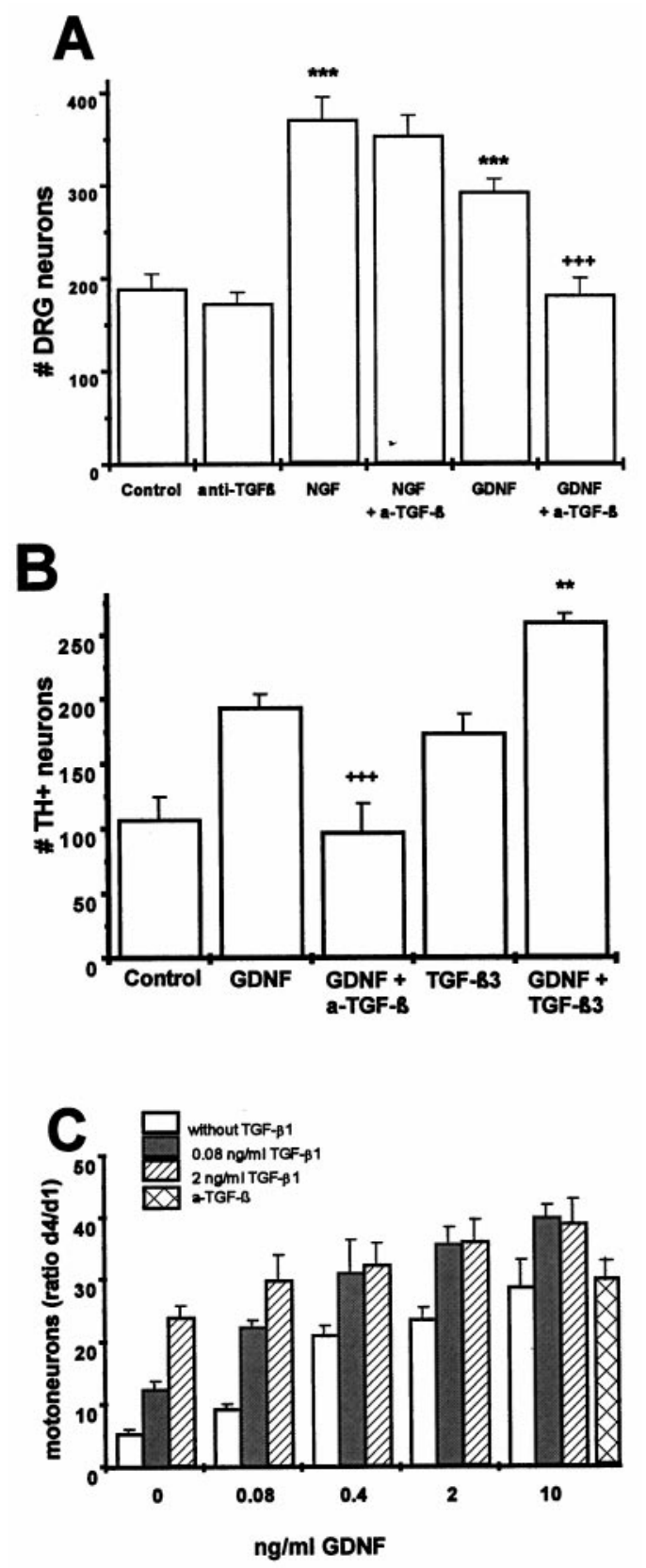

Figure 3. Survival-promoting effect of GDNF and TGF- $\beta$ on rat DRG neurons $(A)$, rat mesencephalic dopaminergic neurons $(B)$, and rat motoneurons $(C) . A$, Dissociated DRG (E14) cultures were treated with GDNF $(10 \mathrm{ng} / \mathrm{ml})$, NGF $(10 \mathrm{ng} / \mathrm{ml})$, anti-TGF- $\beta$ antibodies $(10 \mu \mathrm{g} / \mathrm{ml})$, or NGF or GDNF plus anti-TGF- $\beta$ antibodies in the presence of $10 \%$ horse serum. Data are given as mean $\pm \operatorname{SEM}(n=6), p$ values derived from Student's $t$ test are ${ }^{* * *} p<0.001$ for increased survival as compared with untreated controls and $+++p<0.001$ for decreased survival after antibody treatment. $B$, Dissociated mesencephalic dopaminergic neurons (E14) were cultured at a density of $50,000 \mathrm{cells} / \mathrm{cm}^{2}$ in serum-free medium and treated with GDNF ( $2 \mathrm{ng} / \mathrm{ml})$, TGF- $\beta 3$ ( $2 \mathrm{ng} / \mathrm{ml})$, GDNF plus TGF- $\beta 3$, or GDNF plus anti-TGF- $\beta$ antibodies $(10 \mu \mathrm{g} / \mathrm{ml})$. Data are given as mean \pm SEM $(n=4), p$ values derived from Student's $t$ test are $+++p<0.001$ for decreased survival after antibody treatment. $C$, Dissociated purified motoneurons (E14) were cultured for $4 \mathrm{~d}$ using serumfree medium and treated with GDNF in the absence or presence, respectively, of different amounts of TGF- $\beta 1$ or anti-TGF- $\beta$ antibodies (10 $\mu \mathrm{g} / \mathrm{ml})$. Data are given as mean $\pm \operatorname{SEM}(n=4)$ and expressed in percent of cells present at day 1 .
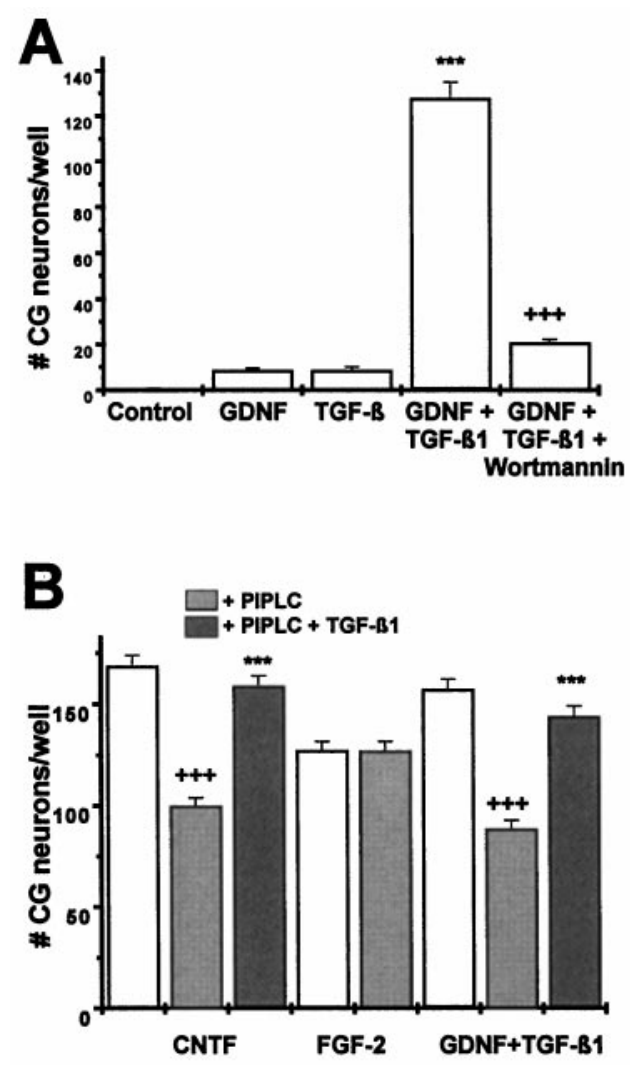

Figure 4. Mechanisms underlying the synergistic actions of GDNF and TGF- $\beta$. $A$, Chick ciliary ganglionic neurons (E8) were treated with GDNF ( $2 \mathrm{ng} / \mathrm{ml})$, TGF- $\beta 1$ ( $2 \mathrm{ng} / \mathrm{ml})$, GDNF plus TGF- $\beta 1$ ( $2 \mathrm{ng} / \mathrm{ml}$ each), and GDNF plus TGF- $\beta 1$ plus wortmannin $(0.25 \mu \mathrm{M})$, a specific inhibitor of PI-3 kinase. Wortmannin abolishes GDNF/TGF- $\beta$-mediated survival of ciliary ganglionic neurons, indicating that PI-3 kinase is an essential mediator in signal transduction of the combined action of GDNF and TGF- $\beta$. Data are given as mean $\pm \operatorname{SEM}(n=6), p$ values derived from Student's $t$ test are $+++p<0.001$ for decreased survival after wortmannin treatment. $B$, Chick ciliary ganglionic neurons were treated with CNTF (2 ng/ml), FGF-2 (10 ng/ml), and GDNF plus TGF- $\beta 1(2 \mathrm{ng} / \mathrm{ml}$ each; white bars) after pretreatment with PIPLC (100 mU, $1 \mathrm{hr})$, which liberates GPI-anchored cytokine receptors from the plasma membrane. PIPLC interferes, as expected, with the survival-promoting effect of CNTF but not that of FGF-2. Pretreatment of isolated ciliary neurons with PIPLC significantly reduces the survival-promoting effect of GDNF and TGF- $\beta$ consistent with the essential role of a GPI-linked GFR $\alpha$ in GDNF signal transduction. Addition of both PIPLC and TGF- $\beta$ to isolated ciliary neurons protects the GPI-linked $\alpha$-receptors, suggesting that the synergistic neurotrophic action of GDNF and TGF- $\beta$ may be caused by a protective action of TGF- $\beta$ on the GFR $\alpha$. Data are given as mean $\pm \operatorname{SEM}(n=6), p$ values derived from Student's $t$ test are $+++p<$ 0.001 for decreased survival after PIPLC treatment and ${ }^{* * *} p<0.001$ for increased survival in the presence of TGF- $\beta 1$.

Eckenstein et al., 1990), possibly the chick homolog of CNTF, and basic fibroblast growth factor (FGF-2; Unsicker et al., 1987). Although CNTF and FGF-2 are synthesized by chromaffin cells (Bieger et al., 1995; K. Krohn, personal communication), previous investigations and the present study reveal that both FGF-2 (Stachowiak et al., 1994; Bieger et al., 1995) and CNTF (see below) are excluded from chromaffin granules. This observation is consistent with the lack of a conventional signal peptide in the FGF-2 and CNTF molecules that would target these proteins to the rough endoplasmic reticulum and Golgi network for secretion. Moreover, chromaffin granules do not contain any detectable CNTF, as assayable using a highly sensitive CNTF-ELISA 


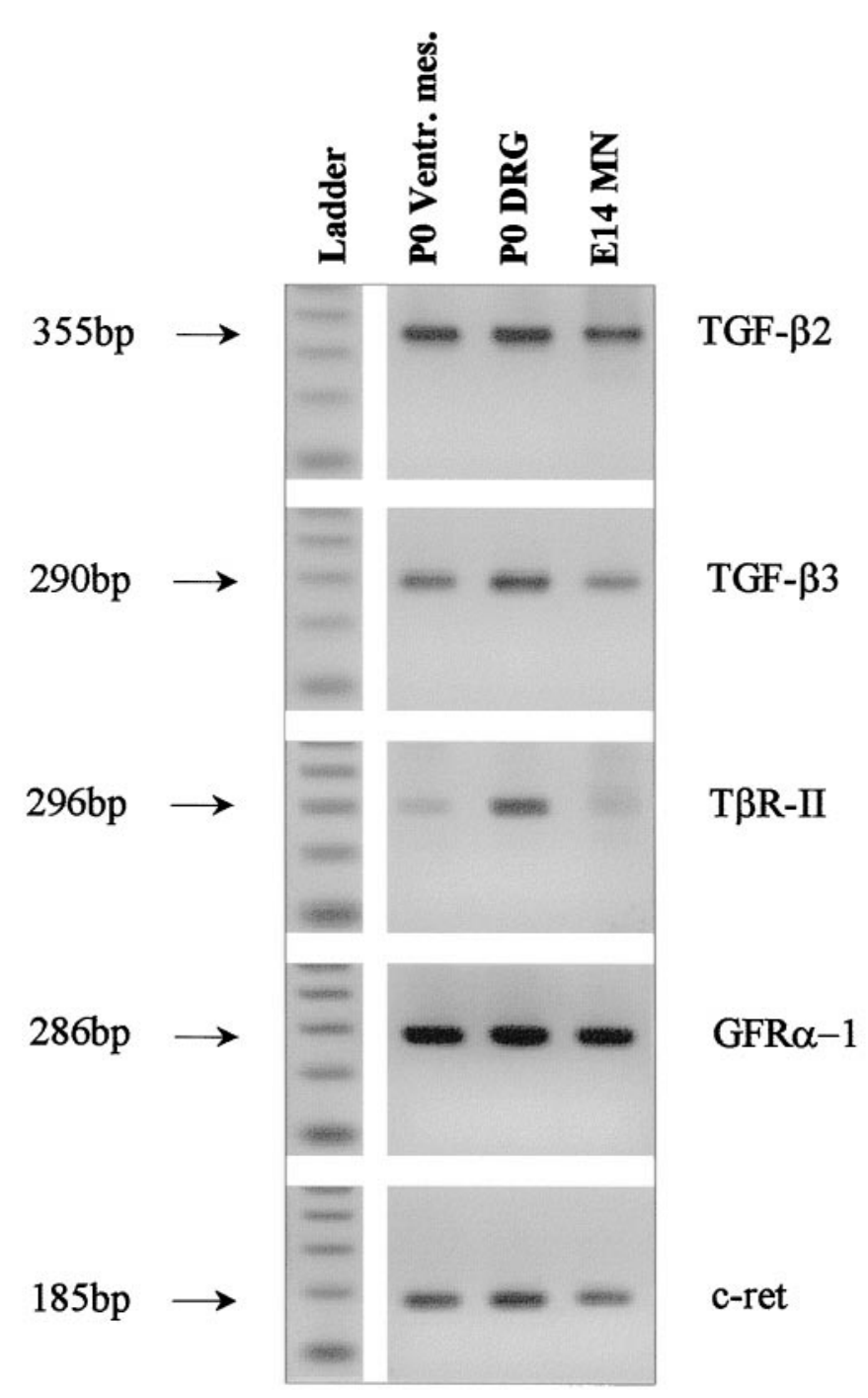

Figure 5. RT-PCR ( 30 cycles) of P0 rat tissues and E14 purified motoneurons with primers specific for TGF- $\beta 2$ (355 bp), TGF- $\beta 3$ (290 bp), T $\beta$ R-II (296 bp), GFR $\alpha-1$ (286 bp), and c-ret (185 bp). PCR products obtained from rat ventral mesencephalon, DRG and purified motoneurons, and a 100 bp ladder are shown. Arrows indicate the size of the PCR products.

technique with a detection limit of $<0.3 \mathrm{ng} / \mathrm{ml}$ (Maysinger et al., 1996; data not shown).

Having shown that (1) chromaffin granule lysates promote ciliary ganglionic neuron survival, and (2) GDNF and TGF- $\beta$ can mimic the neurotrophic effects of CNTF or FGF-2, respectively, on these neurons, we asked whether GDNF and TGF- $\beta$ are synthesized, stored, and released from chromaffin cells. Figure 8 shows that transcripts for GDNF, TGF- $\beta 1$, TGF- $\beta 2$, and TGF- $\beta 3$ can be detected by RT-PCR in bovine chromaffin cells. We next asked whether GDNF was localized within chromaffin granules. Figure 9 shows immunolocalizations of the chromaffin granulespecific marker chromogranin A (Winkler and Fischer-Colbrie, 1992) and GDNF in rat adrenal chromaffin tissue (Fig. 9A) and cultured bovine chromaffin cells (Fig. 9B), suggesting that both immunoreactivities are colocalized in chromaffin granules. Western blotting confirmed that protein lysates from bovine chromaffin granules contained immunoreactive GDNF and TGF- $\beta 1$ at their correct sizes (Fig. 10). We next analyzed supernatants from cultured bovine chromaffin cells for the release of immunoreactive GDNF and TGF- $\beta$ using immunopreciptation and Western blotting. As shown in Figure 10, stimulation with the cholinergic agonist carbachol $\left(10^{-5} \mathrm{M}, 15 \mathrm{~min}\right)$ induced release into the culture supernatant of immunoprecipitable TGF- $\beta 1$ as well as GDNF, suggesting their activity-dependent co-release from chromaffin granules. Stimulation with carbachol in the presence of the $\mathrm{Ca}^{2+}$ channel blocker verapamil reduced amounts of TGF- $\beta 1$ and GDNF in culture supernatants by $\sim 50 \%$ as determined by densitometric evaluation of Western blots. Likewise, exposure of chromaffin cells to the calcium ionophore A 23187 resulted in the accumulation of TGF- $\beta 1$ and GDNF in culture supernatants. These data suggest a regulated activity-dependent release of both TGF- $\beta 1$ and GDNF from a neuronal secretory organelle, the chromaffin granule.

Having shown that GDNF and TGF- $\beta$ are co-stored in and co-released from chromaffin granules, we tested whether neutralizing antibodies to either GDNF or TGF- $\beta$ would block the trophic activity in chromaffin granule lysates for ciliary ganglionic neurons. Figure 7 provides evidence that both antibodies when applied separately significantly reduced the survival-promoting effect of chromaffin granule protein on cultured ciliary ganglionic neurons. Neutralization of both GDNF and TGF- $\beta$ activity completely abolished the activity. These results suggest that GDNF and TGF- $\beta$ are the active "ciliary" neurotrophic components stored in chromaffin granules. More importantly, they underscore the presence, availability, and potency of the neurotrophic activity resulting from the GDNF/TGF- $\beta$ synergism.

\section{DISCUSSION}

\section{The novel scenario of GDNF-mediated neurotrophic actions}

The present study identifies TGF- $\beta$, which is widely expressed in the developing and adult nervous system (Flanders et al., 1991; Unsicker et al., 1991) as an essential component in GDNFmediated neurotrophic actions. Initial studies with GDNF had suggested that the protein fails to elicit neurotrophic effects on most highly purified neuron populations in vitro (Henderson et al., 1994) but promotes neuron survival if administered to complex culture systems (Lin et al., 1993; Ebendal et al., 1995; Buj-Bello et al., 1995; Trupp et al., 1995). Our findings broaden the definition of a neurotrophic factor by incorporating the possibility that two factors that lack a neurotrophic activity when acting separately become neurotrophic when acting in concert. Our findings may also imply that activities of established neurotrophic factors might result, entirely or in part, from endogenously present cofactors. Previous studies have illustrated that the magnitude of effects elicited by neurotrophic factors may be substantially affected by endogenous factors (Krieglstein and Unsicker, 1996b).

\section{The contextual actions of TGF- $\beta$}

TGF- $\beta$ is a member of a still growing superfamily of multifunctional cytokines with prominent roles in development, differentiation, and cell cycle control (for review, see Roberts and Sporn, 1990; Alexandrow and Moses, 1995; Hogan, 1996). Three isoforms, TGF- $\beta 1$, TGF- $\beta 2$, and TGF- $\beta 3$ have been identified in mammalian tissues. In the developing and unlesioned adult nervous system TGF- $\beta 1$ expression seems to be restricted to meninges and choroid plexus, whereas TGF- $\beta 2$ and TGF- $\beta 3$ are coexpressed in astroglial and Schwann cells as well as in many populations of central and peripheral neurons, especially in longrange projecting neurons (for review, see Krieglstein et al., 

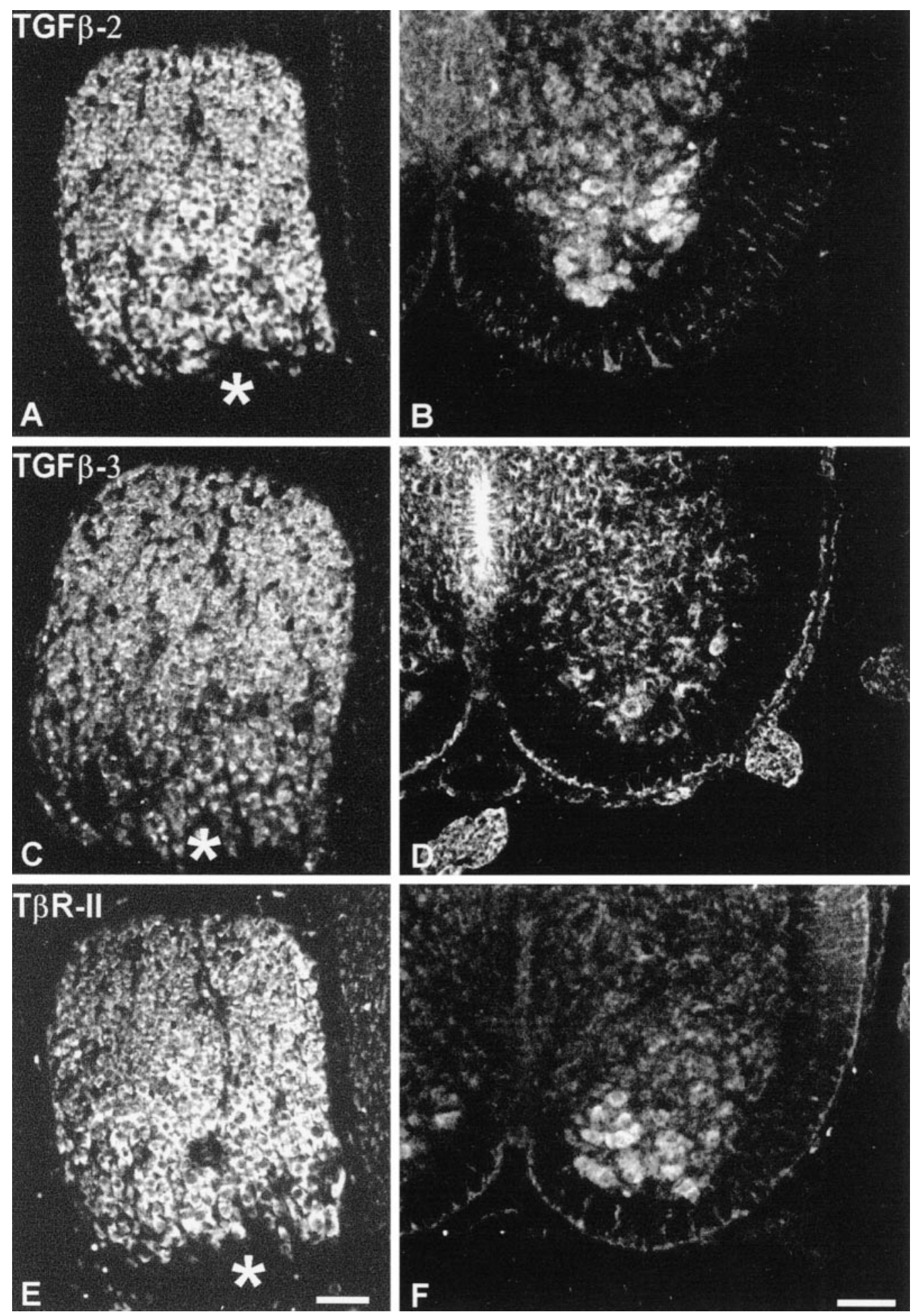

Figure 6. Immunohistochemistry showing localization of TGF- $\beta 2(A, B)$, TGF- $\beta 3(C, D)$, and T $\beta$ R-II $(E, F)$ in chicken DRG (E8; $A, C, E)$ and in rat spinal cord motoneurons (E14; $B, D, F)$. Note strong immunoreactivities in the cell bodies of DRG and motoneurons. Asterisks mark the entrance of dorsal root fibers into the ganglion. Scale bars, $50 \mu \mathrm{m}$.

1995a). Current knowledge on functions of TGF- $\beta$ in the nervous system is deduced from in vitro and in vivo lesioning studies. The available mouse mutants that are defective for either one of the three isoforms (Shull et al., 1992; Kulkarni et al., 1993; Kaartinen et al., 1995; Proetzel et al., 1995; Sanford et al., 1997) have failed to reveal overt deficits in neural structure and function, possibly by virtue of compensatory effects of the remaining isoforms. In contrast, mouse embryos deficient for the TGF- $\beta$ receptor type II (TR $\beta$ II; Oshima et al., 1996) are lethal at E10.5, suggesting the general importance of TGF- $\beta$ signaling in development. Functions of TGF- $\beta$ on neural cells in vitro include regulation of extracellular matrix and proliferation of astroglial cells (Flanders 


\begin{tabular}{|c|c|c|c|c|c|c|}
\hline & \multicolumn{3}{|c|}{ Receptors } & \multicolumn{3}{|l|}{ Ligands } \\
\hline & $\mathrm{T} \beta \mathrm{R}-\mathrm{II}$ & cRet & GFR $\alpha-1$ & TGF- $\beta 2$ & TGF- $\beta 3$ & GDNF \\
\hline \multicolumn{7}{|l|}{ Nigrostriatal system } \\
\hline DA neurons & $+\mathrm{t}$ & $+\mathrm{d}, \mathrm{j}, \mathrm{m}, \mathrm{p}, \mathrm{s}$ & $+\mathrm{m}, \mathrm{p}, \mathrm{s}$ & $+a, b$ & $+a, b$ & \\
\hline Striatum & & & & & & $+\mathrm{i}, \mathrm{n}, \mathrm{o}$ \\
\hline Motoneurons & $+\mathrm{t}, \mathrm{u}$ & $+\mathrm{c}, \mathrm{d}, \mathrm{h}, \mathrm{m}, \mathrm{p}, \mathrm{s}$ & $+\mathrm{m}, \mathrm{p}, \mathrm{s}$ & $+\mathrm{a}, \mathrm{b}$ & $+a, b$ & \\
\hline Muscle & & & & & & $+\mathrm{e}, \mathrm{f}, \mathrm{i}, 1$ \\
\hline DRG neurons & $+\mathrm{t}, \mathrm{u}$ & $+\mathrm{c}, \mathrm{d}, \mathrm{g}, \mathrm{m}, \mathrm{p}, \mathrm{s}$ & $+\mathrm{m}, \mathrm{p}, \mathrm{s}$ & $+a, b$ & $+\mathrm{a}, \mathrm{b}, \mathrm{k}$ & \\
\hline Skin & & & & & & $+\mathrm{e}, \mathrm{i}, 1$ \\
\hline SG (paravertebral) & $+*$ & $+\mathrm{g}, \mathrm{p}$ & $+\mathrm{p}$ & $+\mathrm{a}$ & $+\mathrm{a}, \mathrm{k}$ & \\
\hline Heart & & & & & & $+\mathrm{f}$ \\
\hline CG neurons & $+\mathrm{r}$ & $?$ & $?$ & $+\mathrm{r}$ & $+\mathrm{r}$ & \\
\hline Eye & & & & & & $+\mathrm{f}, \mathrm{i}$ \\
\hline
\end{tabular}

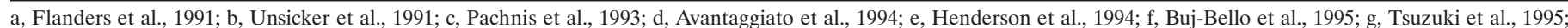

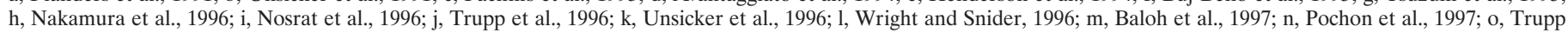

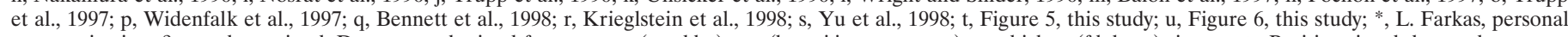
communication; ?, not determined. Data were obtained from mouse (a,c,d,l,p), rat (b,e,g,i,j,m,n,o,q,s,t,u), or chicken (f,h,k,r,u) tissues. +, Positive signal detected.

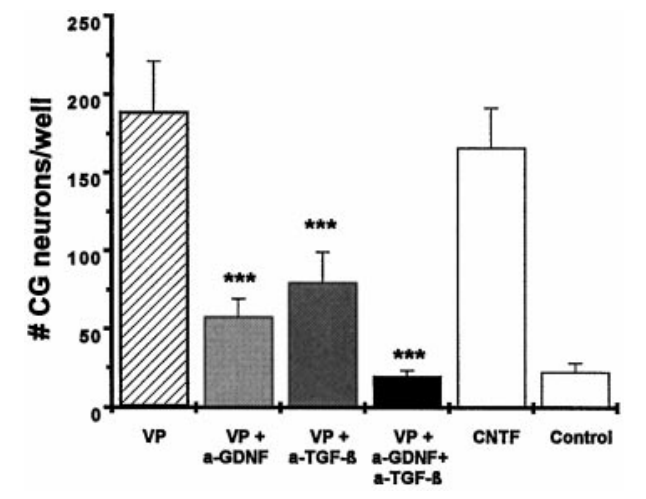

Figure 7. The soluble proteins of chromaffin granules $(V P)$ promote the survival of chick ciliary ganglionic neurons at a level identical to that achieved with a saturating concentration of CNTF $(10 \mathrm{ng} / \mathrm{ml})$. Addition of neutralizing antibodies to either GDNF $(20 \mu \mathrm{g} / \mathrm{ml})$ or the TGF- $\beta \mathrm{s}$ TGF- $\beta 1$, TGF- $\beta 2$, and TGF- $\beta 3(10 \mu \mathrm{g} / \mathrm{ml})$ significantly reduces the promoting effect of VP. Addition of both antibodies completely abolishes the neurotrophic effect of VP $(0.5 \mathrm{mg} / \mathrm{ml})$, suggesting that GDNF and TGF- $\beta$ are the long-sought ciliary neurotrophic proteins contained in VP. Data are given as mean $\pm \operatorname{SEM}(n=6), p$ values derived from Student's $t$ test are ${ }^{* * *} p<0.001$ for decreased survival after antibody treatment.

et al., 1993). TGF- $\beta$ can promote neuron survival in vitro when administered to complex culture systems (Krieglstein et al., 1995b), but shows little or no effect on highly enriched or purified neurons (Krieglstein and Unsicker, 1996b; this study). All TGF- $\beta$ isoforms are known for the strong contextuality of their actions (Nathan and Sporn, 1991). Examples of contextual actions of TGF- $\beta$ on neural cells include stimulation of proliferation of Schwann cells (Schubert, 1992) and inhibition of astroglial cell proliferation in the absence and presence, respectively, of FGF-2 (Flanders et al., 1993). The present study adds a new dimension to the contextual potential of TGF- $\beta$ in the nervous system by identifying TGF- $\beta$ as a molecule that crucially determines the neurotrophic potential of GDNF.

Dependence of GDNF on the presence of a cofactor may not be surprising in light of the reported neurotrophic potential of neurturin and persephin, two recently discovered members of the GDNF subfamily (Kotzbauer et al., 1996; Milbrandt et al., 1998). On dissociated rat sympathetic neurons, neurturin is ineffective

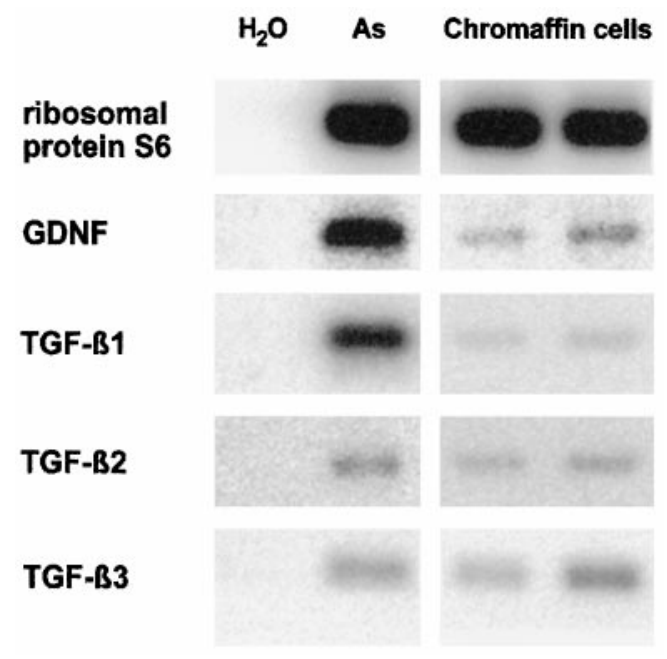

Figure 8. RT-PCR analysis of bovine chromaffin cells (lanes 3 and 4) using primers specific for ribosomal S6 (293 bp), GDNF (415 bp), TGF- $\beta 1$ (279 bp), TGF- $\beta 2$ (359 bp), and TGF- $\beta 3$ (291 bp). Bovine chromaffin cells were analyzed after $18 \mathrm{hr}$ of culture with lanes 3 and 4 , representing two different RNA preparations. In lane 2 RNA from cultured cortical astrocytes is amplified. Lane 1 contains a negative control with water instead of cDNA.

unless neurons are primed with NGF (Creedon et al., 1997); persephin does not support peripheral neurons at all (Milbrandt et al., 1998).

\section{GDNF as a survival factor for peripheral and central neurons}

GDNF is a distantly related member of the TGF- $\beta$ superfamily classified by its structural characteristics (for review, see Lin et al., 1993; Eigenbrot and Gerber, 1997; cf. Unsicker et al., 1998). However, in contrast to TGF- $\beta$, GDNF has been shown to employ for its signaling a heteromeric tyrosine kinase receptor system that consists of a GPI-linked $\alpha$-receptor (GFR $\alpha$, Jing et al., 1996; Treanor et al., 1996) and the receptor tyrosine kinase Ret (Durbec et al., 1996; Trupp et al., 1996). Striking similarities in the phenotypes of mice deficient for GDNF (Moore et al., 1996; Pichel et al., 1996; Sanchez et al., 1996) or its functional receptor Ret (Schuchardt et al., 1994), respectively, suggest sig- 

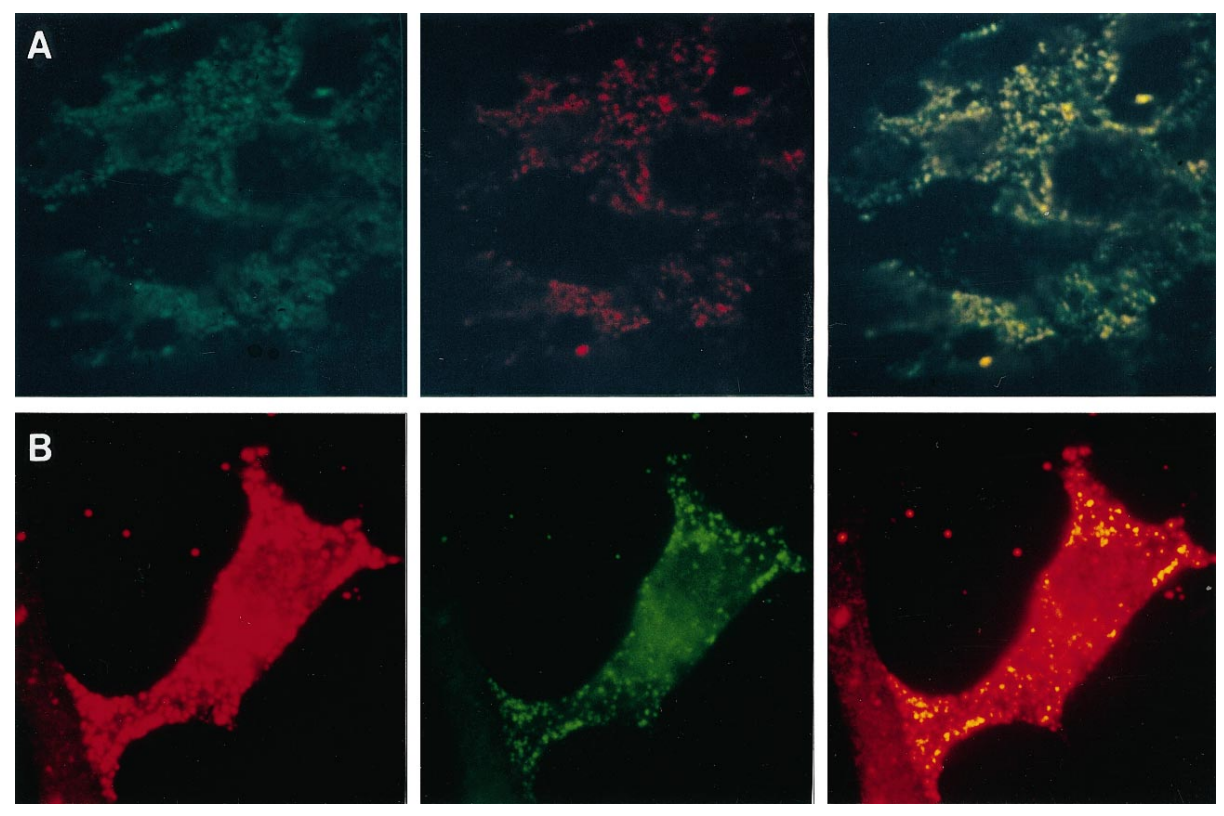

Figure 9. Immunohistochemistry showing granular localization of GDNF in rat adrenal $(A)$ and cultured bovine chromaffin $(B)$ cells. $A$, Confocal fluorescence microscopy of antichromogranin A (monoclonal, green), antiGDNF (polyclonal, red), and its double detection (yellow) using paraffin sections of embryonic rat adrenals (E21). $B$, Fluorescence microscopy of anti-chromogranin A (polyclonal, red), anti-GDNF (monoclonal, green), and its double detection (yellow) of bovine chromaffin cells after $6 \mathrm{~d}$ in culture. nificant interdependence during development. Kidney agenesis and the loss of the enteric nervous system are the prominent features of the mice lacking either GDNF or its receptor Ret. With regard to defects of the developing nervous system deficits in the number of lumbar and trigeminal, but not facial motoneurons, as well as trigeminal sensory, nodose-petrosal, dorsal root ganglionic neurons, and sympathetic neurons have been reported (Moore et al., 1996; Pichel et al., 1996). Surprisingly, the number of TH-immunoreactive neurons in the substantia nigra and the density of dopaminergic nerve terminals in the striatum seemed to be unaffected. The present study underscores the developmental requirements of several neuron populations for GDNF. With regard to dopaminergic neurons GDNF does not seem to be a major survival factor for prenatal neurons, but may be more important in postnatal maturation of the nigrostriatal system. However, our analysis also shows that dopaminergic neurons, like the peripheral neurons tested, essentially require both GDNF and its cofactor TGF- $\beta$.

\section{Molecular bases underlying the GDNF/TGF- $\boldsymbol{\beta}$ cooperativity}

Synergisms of TGF- $\beta$ and other cytokines, most notably FGF-2, in regulating a variety of developmental processes, are well documented in vitro. Thus, TGF- $\beta$ and FGF-2 synergistically promote early embryonic development in the fourth cell cycle (Larson et al., 1992), induce chondrogenesis (Frenz et al., 1994) and angiogenesis (Gajdusek et al., 1993), and, most recently, have been shown to mediate myogenic signals from the neural tube (Stern et al., 1997). However, in none of the above scenarios the underlying molecular mechanisms have been reported. Our study suggests that TGF- $\beta$ /GDNF cooperativity may occur at two crucial steps of signal transduction. First, an important component of GDNF/TGF- $\beta$ signaling has been identified as an activation of PI-3 kinase. GDNF-induced Ret signaling has been shown to activate at least two distinct pathways, the Ras-ERK2 and a PI-3 kinase-involving pathway (van Weering and Bos, 1997). Our data suggest that the PI-3 kinase pathway, which previously has been shown to mediate lamellipodia formation and probably neuritogenesis (van Weering and Bos, 1997), is also important for mediating neuron survival. PI-3 kinase has also been implicated in neurotrophin-mediated neuron survival (Kaplan and Miller, 1997). Second, our data point at another important aspect of GDNF/TGF- $\beta$ cooperativity, the stabilization and/or recruitment of the GPI-linked GDNF $\alpha$ receptor GFR $\alpha$ (Jing et al., 1996; Treanor et al., 1996) by TGF- $\beta$ after PIPLC-mediated hydrolysis of the GPI anchor. Finally, our results might suggest a role for TGF- $\beta$ in recruiting GFR $\alpha$ onto cells, which exclusively express c-ret (Yu et al., 1998).

\section{Biological significance of the GDNF/TGF- $\boldsymbol{\beta}$ cooperativity}

The classic neurotrophic factor concept implies that relevant players are synthesized by the innervated target and retrogradely transported to the cell soma where they exert their functions (Levi-Montalcini, 1987; Thoenen et al., 1987). With regard to GDNF, its synthesis in the target areas of responding neuron populations (Table 1) as well as retrograde transport (Yan et al., 1995; Tomac et al., 1995b) have been well documented. TGF- $\beta$, on the other hand, represents a local factor acting in paracrine and/or autocrine manners (Sporn and Roberts, 1992; Krieglstein and Unsicker, 1996b; Table 1). TGF- $\beta 2$ and TGF- $\beta 3$ proteins are localized in close proximity of as well as in neurons within developing ganglia of the peripheral nervous system, motoneurons in the ventral spinal cord, and dopaminergic neurons in the ventral mesencephalon (Table 1). Studies aiming at revealing a retrograde axonal transport of TGF- $\beta$ have failed so far (Blottner et al., 1996). Thus, a putative scenario for TGF- $\beta$ and GDNF cooperativity could employ retrograde signaling by GDNF in synergy with local actions of TGF- $\beta$. In addition, both TGF- $\beta$ and GDNF may be derived from identical cellular sources, e.g., cortical and hippocampal neurons (Unsicker et al., 1991; Pochon et al., 1997). The well documented colocalization of TGF- $\beta$ and GDNF in these neurons was the rationale for using a model neuron, the neuroendocrine chromaffin cell, for further characterization of the release mechanism. In particular, chromaffin cells permitted us to use the endogenous stores of GDNF and TGF- $\beta$ rather than overexpressing the growth factors. Consistent with the notion that growth factors are acknowledged modulators of synaptic plasticity (Korte and Bonhoeffer, 1997), our data provide evidence that GDNF and TGF- $\beta$ both released from 


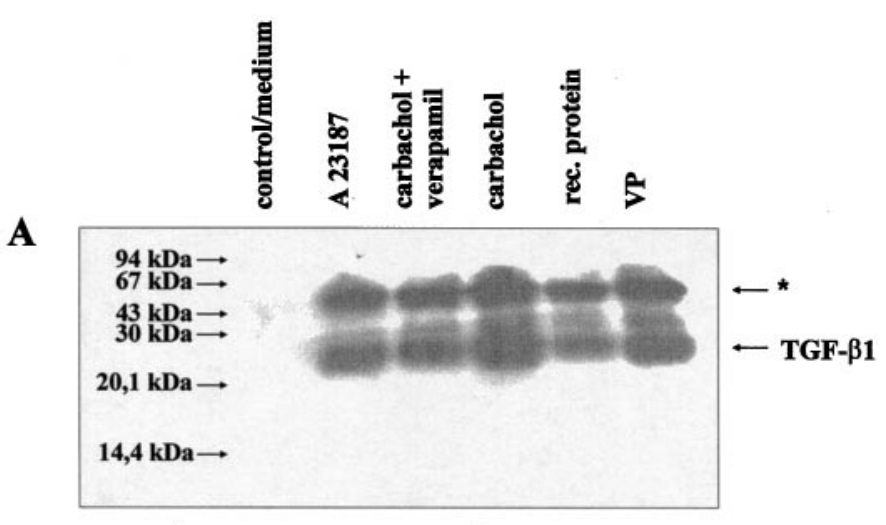

B
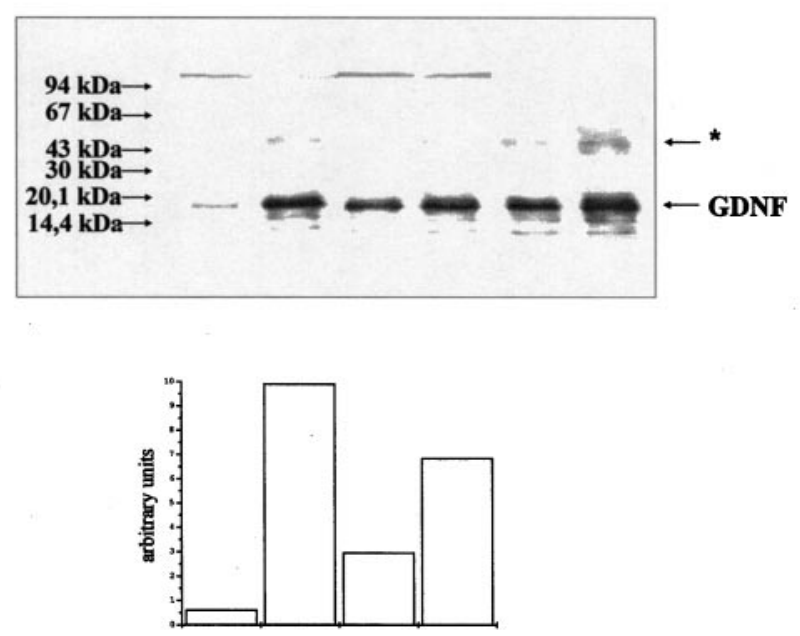

Figure 10. GDNF as well as TGF- $\beta 1$ are released from bovine chromaffin cells after cholinergic stimulation. $A$, Western blot showing immunoprecipitated TGF- $\beta 1$ from supernatants of bovine chromaffin cells after a 15 min stimulation with medium only, with a calcium ionophore A23187, carbachol plus verapamil, or carbachol alone. For comparison, rhTGF- $\beta 1$ and protein extracts from isolated bovine chromaffin granules $(V P)$ were used. The asterisks indicate the position of the primary antibody used for immunoprecipitation. $B$, Western blot showing immunoprecipitated GDNF from the same supernatants of bovine chromaffin cells as used for $A$. For comparison, rhGDNF and VP were used. Bands immunopositive for GDNF were quantified densitometrically and given as arbitrary units.

chromaffin granules after cholinergic stimulation in a calciumdependent manner.

In summary, we have shown that neurotrophic effects that have been attributed to GDNF result from a synergism of GDNF with TGF- $\beta$. Our findings have implications for a general understanding of mechanisms underlying regulation of neuron survival in development and disease, suggesting synergisms of growth factors as an important perspective in future studies. Use of GDNF in clinical trials may benefit from coadministration of TGF- $\beta$ or increasing levels of endogenous TGF- $\beta$. Along the same line, effects of heteromeric GDNF/TGF- $\beta$ complexes may also be exploited for therapeutic interventions.

\section{REFERENCES}

Abe M, Harpel JG, Metz CN, Nunes I, Loskutoff DJ, Rifkin DB (1994) An assay for transforming growth factor- $\beta$ using cells transfected with a plasminogen activator inhibitor-1 promotor-luciferase construct. Anal Biochem 216:276-284.

Alexandrow MG, Moses HL (1995) Transforming growth factor $\beta$ and cell cycle regulation. Cancer Res 55:1452-1457.
Arenas E, Trupp M, Akerud P, Ibanez CF (1995) GDNF prevents degeneration and promotes the phenotype of brain noradrenergic neurons in vivo. Neuron 15:1465-1473.

Avantaggiato V, Dathan NA, Grieco M, Fabien N, Lazzaro D, Fusco A, Simeone A, Santoro M (1994) Developmental expression of the RET protooncogene. Cell Growth Differ 5:305-311.

Baloh RH, Tansey MG, Golden JP, Creedon DJ, Heuckeroth RO, Keck CL, Zimonjic DB, Popescu NC, Johnson Jr EM, Milbrandt J (1997) TrnR2, a novel receptor that mediates neurturin and GDNF signaling through Ret. Neuron 18:793-802.

Barbin G, Manthorpe M, Varon S (1984) Purification of the chick eye ciliary neurotrophic factor. J Neurochem 43:1468-1478.

Beck KD, Valverde J, Alexi T, Poulsen K, Moffat B, Vandlen RA, Rosenthal A, Hefti F (1995) Mesencephalic dopaminergic neurons protected by GDNF from axotomy-induced degeneration in the adult brain. Nature 373:339-341.

Bennett DL, Michael GJ, Ramachandran N, Munson JB, Averill S, Yan Q, McMahon SB, Priestley JV (1998) A distinct subgroup of small DRG cells express GDNF receptor components and GDNF is protective for these neurons after nerve injury. J Neurosci 18:3059-3072.

Bieger SC, Henkel AW, Unsicker K (1995) Localization of basic fibroblast growth factor in bovine adrenal chromaffin cells. J Neurochem 64:1521-1527.

Blottner D, Wolf N, Lachmund A, Flanders KC, Unsicker K (1996) TGF-beta rescues target-deprived preganglionic sympathetic neurons in the spinal cord. Eur J Neurosci 8:202-210.

Bottenstein J, Skaper S, Varon S, Sato G (1980) Selective survival of chick sensory ganglionic cultures utilizing serum-free supplement medium. Exp Cell Res 125:183-190.

Buj-Bello A, Buchman VL, Horton A, Rosenthal A, Davies AM (1995) GDNF is an age-specific survival factor for sensory and autonomic neurons. Neuron 15:821-828.

Burgoyne RD, Morgan A, O'Sullivan AJ (1989) The control of cytoskeletal actin and exocytosis in intact and permeabilized adrenal chromaffin cells: role of calcium and protein kinase C. Cell Signal 1:323-334.

Camu W, Henderson CE (1992) Purification of embryonic rat motoneurons by panning on a monoclonal antibody to the low-affinity NGF receptor. J Neurosci Methods 44:59-70.

Chalazonitis A, Kalberg J, Twardzik DR, Morrison RS, Kessler JA (1992) Transforming growth factor beta has neurotrophic actions on sensory neurons in vitro and is synergistic with nerve growth factor. Dev Biol 152:121-132.

Creedon DJ, Tansey MG, Baloh RH, Osborne PA, Lampe PA, Fahrner TJ, Heuckeroth RO, Milbrandt J, Johnson Jr EM (1997) Neurturin shares receptors and signal transduction pathways with glial cell linederived neurotrophic factor in sympathetic neurons. Proc Natl Acad Sci USA 94:7018-7023.

Durbec P, Marcos-Gutierrez CV, Kilkenny C, Grigoriou M, Wartiowaara K, Suvanto P, Smith D, Ponder B, Costantini F, Saarma M, Sariola H, Pachnis V (1996) GDNF signalling through the ret receptor tyrosine kinase. Nature 381:789-793.

Ebendal T, Tomac A, Hoffer BJ, Olson L (1995) Glial cell line-derived neurotrophic factor stimulates fiber formation and survival in cultured neurons from peripheral autonomic ganglia. J Neurosci Res 40:276-284.

Eckenstein FP, Esch F, Holbert T, Blacher RW, Nishi R (1990) Purification and characterization of a trophic factor for embryonic peripheral neurons: comparison with fibroblast growth factors. Neuron 4:623-631.

Eigenbrot C, Gerber N (1997) X-ray structure of glial cell-derived neurotrophic factor at $1.9 \mathrm{~A}$ resolution and implications for receptor binding. Nat Struct Biol 4:435-438.

Farkas L, Suter-Crazzolara C, Unsicker K (1997) GDNF induces the calretinin phenotype in cultures of embryonic striatal neurons. J Neurosci Res 50:361-372.

Ferro-Novick S, Jahn R (1994) Vesicle fusion from yeast to man. Nature 370:191-193.

Flanders KC, Lüdecke G, Engels S, Cissel DS, Roberts AB, Kondaiah P, Lafyatis R, Sporn MB, Unsicker K (1991) Immunohistochemical localization of transforming growth factor- $\beta$ s in the nervous system of the mouse embryo. Development 113:183-191.

Flanders KC, Lüdecke G, Renzig J, Hamm C, Cissel DS, Unsicker K (1993) Effect of TGF- $\beta$ s and bFGF on astroglial cell growth and gene expression in vitro. Mol Cell Neurosci 4:406-417.

Frenz DA, Liu W, Williams JD, Hatcher V, Galinovic-Schwartz V, Flanders KC, Van de Water TR (1994) Induction of chondrogenesis: 
requirement for synergistic interaction of basic fibroblast growth factor and transforming growth factor-beta. Development 120:415-424.

Gajdusek CM, Luo Z, Mayberg MR (1993) Basic fibroblast growth factor and transforming growth factor beta-1: synergistic mediators of angiogenesis in vitro. J Cell Physiol 157:133-144.

Gash DM, Zhang Z, Ovadia A, Cass WA, Yi A, Simmerman L, Russell D, Martin D, Lapchak PA, Collins F, Hoffer BJ, Gerhardt GA (1996) Functional recovery in parkinsonian monkeys treated with GDNF. Nature 380:252-255.

Heller S, Finn TP, Huber J, Nishi R, Geissen M, Puschel AW, Rohrer H (1995) Analysis of function and expression of the chick GPA receptor (GPAR alpha) suggests multiple roles in neuronal development. Development 121:2681-2693.

Henderson CE, Phillips HS, Pollock RA, Davies AM, Lemeulle C, Armanini MP, Simpson LC, Moffet B, Vandlen RA, Koliatsos VE, Rosenthal A (1994) GDNF: a potent survival factor for motoneurons present in peripheral nerve and muscle. Science 266:1062-1064.

Hoffer BJ, Hoffman A, Bowenkamp K, Huettl P, Hudson J, Martin D, Lin LFH, Gerhardt GA (1994) Glial cell line-derived neurotrophic factor reverses toxin-induced injury to midbrain dopaminergic neurons in vivo. Neurosci Lett 182:107-111.

Hogan BL (1996) Bone morphogenetic proteins: multifunctional regulators of vertebrate development. Genes Dev 10:1580-1594.

Huttner WB, Gerdes H-H, Rosa P (1991) Chromogranins/secretogranins: widespread constituents of the secretory granule matrix in endocrine cells and neurons. In: Markers from neural and endocrine cells: molecular and cell biology, diagnostic applications (Gratzl M, ed), pp 93-131. Weinheim: VCH.

Jahn R, Südhoff TC (1994) Synaptic vesicles and exocytosis. Annu Rev Neurosci 17:219-246.

Jing S, Wen D, Yu Y, Holst PL, Luo Y, Fang M, Tamir R, Antonio L, Hu Z, Cupples R, Louis JC, Hu S, Altrock BW, Fox GM (1996) GDNFinduced activation of the ret protein tyrosine kinase is mediated by GDNFR-alpha, a novel receptor for GDNF. Cell 85:1113-1124.

Kaartinen V, Voncken JW, Shuler C, Warburton D, Bu D, Heisterkamp N, Groffen J (1995) Abnormal lung development and cleft palate in mice lacking TGF- $\beta 3$ indicates defects of epithelial-mesenchymal interaction. Nat Genet 11:415-421.

Kaplan DR, Miller FD (1997) Signal transduction by the neurotrophin receptors. Curr Opin Cell Biol 9:213-221.

Kingsley DM (1994) The TGF- $\beta$ superfamily: new members, new receptors, and new genetic tests of function in different organisms. Genes Dev 8:133-146.

Korte M, Bonhoeffer T (1997) Activity-dependent synaptic plasticity: a new face of action for neurotrophins. Mol Psychiatry 2:197-199.

Kotzbauer PT, Lampe PA, Heuckeroth RO, Golden JP, Creedon DJ, Johnson Jr EM, Milbrandt J (1996) Neurturin, a relative of glial-cellline-derived neurotrophic factor. Nature 384:467-470.

Krieglstein K, Unsicker K (1994) Transforming growth factor- $\beta$ promotes survival of midbrain dopaminergic neurons and protects them against $N$-methyl-4-phenylpyridinium ion toxicity. Neuroscience 63:1189-1196.

Krieglstein K, Unsicker K (1995) Bovine chromaffin granules contain and release a transforming growth factor- $\beta$-like activity. J Neurochem 65:1423-1426.

Krieglstein K, Unsicker K (1996a) Proteins from chromaffin granules promote survival of dorsal root ganglionic neurons: comparison with neurotrophins. Dev Brain Res 93:10-17.

Krieglstein K, Unsicker K (1996b) Distinct modulatory actions of TGF- $\beta$ and LIF on neurotrophin-mediated survival of developing sensory neurons. Neurochem Res 21:849-856.

Krieglstein K, Unsicker K (1997) Proteins from chromaffin granules promote survival of mesencephalic dopaminergic neurons by an EGFreceptor ligand-mediated pathway. J Neurosci Res 48:18-30.

Krieglstein K, Rufer M, Suter-Crazzolara C, Unsicker K (1995a) Neural functions of the transforming growth factor $\beta$. Int $\mathrm{J}$ Dev Neurosci 13:301-315.

Krieglstein K, Suter-Crazzolara C, Fischer WH, Unsicker K (1995b) TGF- $\beta$ superfamily members promote survival of midbrain dopaminergic neurons and protect them against $\mathrm{MPP}+$ toxicity. EMBO J $14: 736-742$.

Krieglstein K, Deimling F, Suter-Crazzolara C, Unsicker K (1996) Expression and localization of GDNF in developing and adult adrenal chromaffin cells. Cell Tissue Res 286:263-268.

Krieglstein K, Farkas L, Unsicker K (1998) TGF- $\beta$ regulates the survival of ciliary ganglionic neurons synergistically with ciliary neurotrophic factor and neurotrophins. J Neurobiol, in press.

Kulkarni AB, Huh C-G, Becker D, Geiser A, Lyght M, Flanders KC, Roberts AB, Sporn MB, Ward JM, Karlsson S (1993) Transforming growth factor $\beta 1$ null mutation in mice causes excessive inflammatory response and early death. Proc Natl Acad Sci USA 90:770-774.

Lachmund A, Gehrke D, Krieglstein K, Unsicker K (1994) Trophic factors from chromaffin granules promote survival of peripheral and central nervous system neurons. Neuroscience 62:361-370.

Larson RC, Ignotz GG, Currie WB (1992) Transforming growth factor $\beta$ and basic fibroblast growth factor synergistically promote early bovine embryo development during the fourth cell cycle. Mol Reprod Dev 33:432-435.

Levi-Montalcini R (1987) The nerve growth factor 35 years later. Science 237:1154-1162.

Lin LFH, Doherty DH, Lile JD, Bektesh S, Collins F (1993) GDNF - a glial cell line-derived neurotrophic factor for midbrain dopaminergic neurons. Science 260:1130-1132.

Martinou J-C, le van Thai A, Valette A, Weber MJ (1990) Transforming growth factor $b_{1}$ is a potent survival factor for rat embryo motoneurons in culture. Dev Brain Res 52:175-181.

Maysinger D, Krieglstein K, Filipovic-Grcic J, Sendtner M, Unsicker K, Richardson P (1996) Microencapsulated ciliary neurotrophic factor: physical properties and biological activities. Exp Neurol 138:177-188.

Milbrandt J, de Sauvage FJ, Fahrner TJ, Baloh RH, Leitner ML, Tansey MG, Lampe PA, Heuckeroth RO, Kotzbauer PT, Simburger KS, Golden JP, Davies JA, Vejsada R, Kato AC, Hynes M, Sherman D, Nishimura M, Wang L-C, Vandlen R, Moffat B, Klein RD, Poulsen K, Gray C, Garces A, Henderson CE, Philips HS, Johnson Jr EM (1998) Persephin, a novel neurotrophic factor related to GDNF and neurturin. Neuron 20:245-253.

Moore MW, Klein RD, Farinas I, Sauer H, Armanini M, Phillips H, Reichardt LF, Ryan AM, Carver-Moore K, Rosenthal A (1996) Renal and neuronal abnormalities in mice lacking GDNF. Nature 382:76-79.

Nakamura M, Ohta K, Hirokawa K, Fukushima M, Uchino M, Ando M, Tanaka H (1996) Developmental and denervation changes in c-ret proto-oncogene expression in chick motoneurons. Brain Res Mol Brain Res 39:1-11.

Nathan C, Sporn M (1991) Cytokines in context. J Cell Biol 113:981-986.

Neher E, Marty A (1982) Discrete changes of cell membrane capacitance observed under conditions of enhanced secretion in bovine adrenal chromaffin cells. Proc Natl Acad Sci USA 79:6712-6716.

Nosrat CA, Tomac A, Lindqvist E, Lindskog S, Humpel C, Stromberg I, Ebendal T, Hoffer BJ, Olson L (1996) Cellular expression of GDNF mRNA suggests multiple functions inside and outside the nervous system. Cell Tissue Res 286:191-207.

Oshima M, Oshima H, Taketo MM (1996) TGF- $\beta$ receptor type II deficiency results in defects of yolk sac hematopoiesis and vasculogenesis. Dev Biol 179:297-302.

Pachnis V, Mankoo B, Costantini F (1993) Expression of the c-ret protooncogene during mouse embryogenesis. Development 119:1005-1017.

Pichel JP, Shen L, Sheng HZ, Granholm A-C, Drago J, Grinberg A, Lee EJ, Huang SP, Saarma M, Hoffer BJ, Sariola H, Westphal H (1996) Defects in enteric innervation and kidney development in mice lacking GDNF. Nature 382:73-76.

Pochon NA-M, Menoud A, Tseng JL, Zurn AD, Aebischer P (1997) Neuronal GDNF expression in the adult rat nervous system identified by in situ hybridization. Eur J Neurosci 9:463-471.

Poulsen KT, Armanini MP, Klein RD, Hynes MA, Phillips HS, Rosenthal A (1994) TGF $\beta 2$ and TGF $\beta 3$ are potent survival factors for midbrain dopaminergic neurons. Neuron 13:1245-1252.

Proetzel G, Pawlowski SA, Wiles MV, Yin M, Boivin GP, Howles PN, Ding J, Ferguson MW, Doetschman T (1995) Transforming growth factor-beta 3 is required for secondary palate fusion. Nat Genet 11:409-414.

Roberts AB, Sporn MB (1990) The transforming growth factors- $\beta$ s. In: Handbook of experimental pharmacology, Vol 95 (Sporn MB, Roberts AB, eds), pp 419-472. Heidelberg: Springer.

Sanchez MP, Silos-Santiago I, Frisen J, He B, Lira SA, Barbacid M (1996) Renal agenesis and the absence of enteric neurons in mice lacking GDNF. Nature 382:70-73.

Sanford LP, Ormsby I, Gittenberger de Groot AC, Sariola H, Friedman R, Boivin GP, Cardell EL, Doetschman T (1997) TGF- $\beta 2$ knockout 
mice have multiple developmental defects that are non-overlapping with other TGF $\beta$ knockout phenotypes. Development 124:2659-2670.

Sauer H, Rosenblad C, Björklund A (1995) GDNF but not TGF- $\beta 3$ prevents delayed degeneration of nigral dopaminergic neurons following striatal 6-hydroxydopamine lesion. Proc Natl Acad Sci USA 92:8935-8939.

Schubert D (1992) Synergistic interactions between transforming growth factor beta and fibroblast growth factor regulate Schwann cell mitosis. J Neurobiol 23:143-148.

Schuchardt A, D’Agati V, Larsson-Blomberg L, Costantini F, Pachnis V (1994) Defects in the kidney and enteric nervous system of mice lacking the tyrosine kinase receptor Ret. Nature 367:380-383.

Shull MM, Ormsby I, Kier AB, Pawlowski S, Diebold RJ, Yin M, Allen R, Sidman C, Proetzel G, Calvin D, Annunziata N, Doetschman T (1992) Targeted disruption of the mouse transforming growth factor- $\beta 1$ gene results in multifocal inflammatory disease. Nature 359:693-699.

Sporn MB, Roberts AB (1992) Autocrine Secretion: 10 years later. Ann Intern Med 117:408-414.

Stachowiak MK, Moffett J, Joy A, Puchacz E, Florkiewicz R, Stachowiak EK (1994) Regulation of bFGF gene expression and subcellular distribution of bFGF protein in adrenal medullary cells. J Cell Biol 127:203-223.

Stern HM, Lin-Jones J, Hauschka SD (1997) Synergistic interactions between bFGF and a TGF- $\beta$ family member may mediate myogenic signals from neural tube. Development 124:3511-3523.

Thoenen H, Bandtlow C, Heumann R (1987) The physiological function of nerve growth factor in the central nervous system: comparison with the periphery. Rev Physiol Biochem Pharmacol 109:145-178.

Tomac A, Lindqvist E, Lin LFH, Ögren SO, Young D, Hoffer BJ, Olson L (1995a) Protection and repair of the nigrostriatal dopaminergic system by GDNF in vivo. Nature 373:335-339.

Tomac A, Widenfalk J, Lin LF, Kohno T, Ebendal T, Hoffer BJ, Olson L (1995b) Retrograde axonal transport of glial cell line-derived neurotrophic factor in the adult nigrostriatal system suggests a trophic role in the adult. Proc Natl Acad Sci USA 92:8274-8278.

Treanor JJS, Goodman L, de Sauvage F, Stone DM, Poulsen KT, Beck CD, Gray C, Armanini MP, Pollock RA, Hefti F, Phillips HS, Goddard A, Moore MW, Buj-Bello A, Davies AM, Asai N, Takahashi M, Vandlen R, Henderson CE, Rosenthal A (1996) Characterization of a multicomponent receptor for GDNF. Nature 382:80-83.

Trupp M, Ryden M, Jornvall H, Funakoshi H, Timmusk T, Arenas E, Ibanez CF (1995) Peripheral expression and biological activities of GDNF, a new neurotrophic factor for avian and mammalian peripheral neurons. J Cell Biol 130:137-148.

Trupp M, Arenas E, Fainzilber M, Nilsson AS, Sieber BA, Grigoriou M, Kilkenny C, Salazar-Grueso E, Pachnis V, Arumäe U, Sariola H, Saarma M, Ibanez CF (1996) Functional receptor for GDNF encoded by the c-ret proto-oncogene. Nature 381:785-789.

Trupp M, Belluardo N, Funakoshi H, Ibanez CF (1997) Complementary and overlapping expression of glial cell line-derived neurotrophic factor (GDNF), c-ret proto-oncogene, and GDNF receptor-alpha indicates multiple mechanisms of trophic actions in the adult rat CNS. J Neurosci $17: 3554-3567$.
Tsuzuki T, Takahashi M, Asai N, Iwashita T, Matsuyama M, Asai J (1995) Spatial and temporal expression of the ret proto-oncogene product in embryonic, infant and adult rat tissues. Oncogene 10:191-198.

Unsicker K (1993) The chromaffin cell: paradigm in cell development and growth factor biology. J Anat 183:207-221.

Unsicker K, Krieglstein K (1996) Growth factors in chromaffin cells. Prog Neurobiol 48:307-324.

Unsicker K, Lietzke R (1987) Chromaffin cells: modified neurons that are both targets and storage sites of neuronotrophic and neurite promoting factors. In: Glial-neuronal communication in development and regeneration (Althaus H, Seifert W, eds), pp 365-384. Heidelberg: Springer.

Unsicker K, Griesser GH, Lindmar R, Löffelholz U, Wolf U (1980) Establishment, characterization and fibre outgrowth of isolated bovine adrenal medullary cells in long-term cultures. Neuroscience 5:1445-1460.

Unsicker K, Reichert-Preibsch H, Schmidt R, Pettmann B, Labourdette G, Sensenbrenner M (1987) Astroblast and fibroblast growth factors have neurotrophic functions for peripheral and central nervous system neurons. Proc Natl Acad Sci USA 84:5459-5463.

Unsicker K, Flanders KC, Cissel DS, Lafyatis R, Sporn MB (1991) Transforming growth factor beta isoforms in the adult rat central and peripheral nervous system. Neuroscience 44:613-625.

Unsicker K, Meier C, Krieglstein K, Sartor BM, Flanders KC (1996) Expression, localization, and function of transforming growth factor- $\beta \mathrm{s}$ in embryonic chick spinal cord, hindbrain, and dorsal root ganglia. J Neurobiol 29:262-276.

Unsicker K, Suter-Crazzolara C, Krieglstein K (1998) Neurotrophic roles of GDNF and related factors. In: Neurotrophic factors, handbook of experimental pharmacology, Vol 134 (Hefti F, ed), pp 189-224. Heidelberg: Springer.

van Weering DHJ, Bos JL (1997) Glial cell line-derived neurotrophic factor induces ret-mediated lamellipodia formation. J Biol Chem 272:249-254.

Widenfalk J, Nosrat C, Tomac A, Westphal H, Hoffer B, Olson L (1997) Neurturin and glial cell line-derived neurotrophic factor receptor- $\beta$ (GDNFR- $\beta$ ), novel proteins related to GDNF and GDNFR- $\alpha$ with specific cellular patterns of expression suggesting roles in the developing and adult nervous system and in peripheral organs. J Neurosci 17:8506-8519.

Winkler H, Fischer-Colbrie R (1992) The chromogranins A and B: the first 25 years and future perspectives. Neuroscience 49:497-528.

Wright DE, Snider WD (1996) Focal expression of glial cell line-derived neurotrophic factor in developing mouse limb bud. Cell Tissue Res 286:209-217.

Yan Q, Matheson C, Lopez OT (1995) In vivo neurotrophic effects of GDNF on neonatal and adult facial motor neurons. Nature 373:341-344.

Yu T, Scully S, Yu Y, Fox GM, Jing S, Zhou R (1998) Expression of GDNF family receptor components during development: implications in the mechanisms of interaction. J Neurosci 18:4684-4696. 